\title{
Evaluation of asymmetric Oxygen Minimum Zones in the tropical Pacific: a basin-scale OGCM-DMEC V1.0
}

\author{
Kai Wang ${ }^{1}$, Xiujun Wang ${ }^{1,2^{*}}$, Raghu Murtugudde ${ }^{2}$, Dongxiao Zhang ${ }^{3}$, Rong-Hua Zhang ${ }^{4}$ \\ ${ }^{1}$ College of Global Change and Earth System Science, Beijing Normal University, Beijing 100875, China \\ $5 \quad{ }^{2}$ Earth System Science Interdisciplinary Center, University of Maryland, College Park, Maryland 20740, USA \\ ${ }^{3}$ JISAO, University of Washington and NOAA, Pacific Marine Environmental Laboratory, Seattle, Washington 98115, USA \\ ${ }^{4}$ Institute of Oceanology, Chinese Academy of Sciences, Qingdao, Shandong 266071, China
}

Correspondence to: Xiujun Wang (xwang@bnu.edu.cn)

Abstract. The tropical Pacific Ocean holds the world's two largest Oxygen Minimum Zones (OMZs), showing a prominent

10 hemispheric asymmetry, with a much stronger and broader OMZ north of the equator. However, there is a lack of quantitative assessments of physical and biological regulations on the asymmetry of tropical Pacific OMZs. Here, we apply a fully coupled basin-scale model (OGCM-DMEC V1.0) to investigate the impacts of physical supply and biological consumption on the dynamics of OMZs in the tropical Pacific. We first utilize observational data to evaluate and improve our model simulation, and find that mid-depth DO is more sensitive to the parameterization of background diffusion.

15 Enhanced background diffusion results in higher DO concentrations at mid-depth, leading to significant improvement of our model capability to reproduce the asymmetric OMZs. Our study shows that while physical supply of DO is increased in majority of the tropical Pacific due to enhanced background diffusion, there is little increase in the largest OMZ to the north. Interestingly, enhanced background diffusion results in lower rates of biological consumption over $\sim 300-1000 \mathrm{~m}$ in the entire basin, which is associated with redistribution of dissolved organic matter (DOM). Our analyses demonstrate that weaker physical supply in the ETNP is the dominant process responsible for the asymmetric DO in the core OMZs ( 200-600 m) while higher biological consumption to the north plays a larger role in regulating DO concentration beneath the OMZs ( 600-800 m), with implication for the asymmetric OMZs. This study highlights the roles of physical supply and biological consumption in shaping the asymmetric OMZs in the tropical Pacific, underscoring the need to understand both physical and biological processes for accurate projections of DO variability.

\section{Introduction}

Photosynthesis and respiration are important processes in all ecosystems on the Earth, with carbon and oxygen being the two main elements. The carbon cycle has garnered much attentions and made significant process in both the observations and modelling of biological processes (e.g., uptake of $\mathrm{CO}_{2}$ and respiration), and physical/chemical processes (e.g., the fluxes between the atmosphere, land and ocean). However, the oxygen cycle has received much less attention despite its large role in the earth system (Breitburg et al., 2018; Oschlies et al., 2018). 
Dissolved oxygen (DO) is a sensitive indicator of physical and biogeochemical processes in the ocean thus a key parameter for understanding the ocean's role in the climate system (Stramma et al., 2010). In addition to photosynthesis and respiration, the distribution of DO in the world's oceans is also regulated by air-sea gas exchange, ocean circulation and ventilation (Bopp et al., 2002; Brandt et al., 2015; Levin, 2018). Unlike most dissolved nutrients that display an increase in concentration with depth, DO concentration is generally low at mid-depth of the ocean. The most remarkable feature in the oceanic oxygen dynamics is the so-called Oxygen Minimum Zone (OMZ) that is often present below $200 \mathrm{~m}$ in the open oceans (Karstensen et al., 2008; Stramma et al., 2008), where DO concentration is less than $20 \mathrm{mmol} \mathrm{m}^{-3}$ (Gilly et al., 2013; Paulmier and Ruiz-Pino, 2009).

40

The world's two largest OMZs are observed at $200-700 \mathrm{~m}$ in the Eastern Tropical North Pacific (ETNP) and South Pacific (ETSP), showing a peculiar asymmetric structure across the equator, i.e., a much larger volume of suboxic water $(<20 \mathrm{mmol}$ $\mathrm{m}^{-3}$ ) to the north than to the south (Karstensen et al., 2008; Paulmier and Ruiz-Pino, 2009; Stramma et al., 2008). It is known that OMZs are caused by the biological consumption associated with remineralization of organic matter (OM), and weak physical supply of DO due to sluggish subsurface ocean circulation and ventilation (Brandt et al., 2015; Kalvelage et al., 2015). Although there have been a number of observation based analyses addressing the dynamics of OMZs in the tropical Pacific during the past decade (Czeschel et al., 2012; Garçon et al., 2019; Schmidtko et al., 2017; Stramma et al., 2010), our understanding is uncompleted in terms of the underlying mechanisms that regulate DO dynamics at mid-depth due to the limitation of available data (Oschlies et al., 2018; Stramma et al., 2012).

Large-scale physical-biogeochemical models have become a useful tool for advance understanding of the oceanic oxygen cycle (Cabré et al., 2015; Ward et al., 2018; Williams et al., 2014), and have demonstrated that physical processes such as ventilation and circulation play a dominant role in regulating the dynamics of tropical OMZs (Deutsch et al., 2006; Ito et al., 2019; Montes et al., 2014; Stramma et al., 2010). However, many current global and regional models could not consistently reproduce the dynamics of tropical Pacific OMZs (Cabré et al., 2015; Stramma et al., 2012), which may be related to unresolved transport process, unaccounted biological consumption or missing biogeochemical feedbacks in the models (Keller et al., 2016; Palter and Trossman, 2018; Shigemitsu et al., 2017). Moreover, there has been a lack of quantitative assessments on the relative roles of physical supply and biological consumption in driving the tropical asymmetric OMZs using validated models (Keller et al., 2016; Oschlies et al., 2018).

A fully coupled basin-scale physical-biogeochemical model (OGCM-DMEC V1.0) was developed for the tropical Pacific (Wang et al., 2008; Wang et al., 2015; Wang et al., 2009), which shows capability of reproducing observed spatial and temporal variations in physical, nutrient and carbon fields. In this study, we use the validated basin-scale model to evaluate the simulation of oxygen cycle, focusing on the dynamics of mid-depth DO. We first carry out model evaluation and 
65 validation by using observational DO data to improve the simulation of OMZs in the tropical Pacific. Then, we use the improved model to quantify how physical supply and biological consumption regulate the dynamics of DO at mid-depth. The objective of this study is to advance our model capacity to simulate the oceanic oxygen cycle, and to explore the mechanisms driving the asymmetric OMZs in the tropical Pacific.

\section{Model description}

70 The OGCM-DMEC V1.0 is a fully coupled basin-scale physical-biogeochemical model that has shown a good model-data agreement in the carbon cycle for the tropical Pacific Ocean (Wang et al., 2015). A brief description is presented in this section.

\subsection{Ocean physical model}

75 The basin-scale OGCM, a reduced-gravity, primitive-equation, sigma-coordinate model, is coupled to an advective atmospheric model (Murtugudde et al., 1996). There are 20 layers with variable thicknesses in the OGCM. The mixed layer (the upper-most layer) is determined by the Chen mixing scheme (Chen et al., 1994), which varies from $10 \mathrm{~m}$ to $50 \mathrm{~m}$ on the equator. The remaining layers in the euphotic zone are approximately $10 \mathrm{~m}$ in thickness. The model domain is between $30^{\circ} \mathrm{S}$ and $30^{\circ} \mathrm{N}$, and zonal resolution is $1^{\circ}$. Meridional resolution varies between $0.3^{\circ}$ and $0.6^{\circ}$ over $15^{\circ} \mathrm{S}-15^{\circ} \mathrm{N}\left(1 / 3^{\circ}\right.$ over $10^{\circ \circ} \mathrm{S}-$

$8010^{\circ} \mathrm{N}$ ), and increases to $2^{\circ}$ in the southern and northern "sponge layers" (the $20^{\circ}-30^{\circ}$ bands) where temperature, salinity, nitrate and iron are gradually relaxed back towards the observed climatological seasonal means from the World Ocean Atlas, 2013 (WOA2013: http://www.nodc.noaa.gov/OC5/woa13/pubwoa13.html).

The model is forced by atmospheric conditions: climatological monthly means of solar radiation and cloudiness, and

85 interannual, 6-day means of precipitation and surface wind stress. Precipitation is from ftp://ftp.cdc.noaa.gov/Datasets/gpcp, and surface wind stresses from the National Centers for Environmental Prediction (NCEP) reanalysis (Kalnay et al., 1996). Air temperature and humidity above the ocean surface are computed by the atmospheric mixed layer model. Initial conditions were obtained from outputs of an interannual hindcast simulation over 1948-1978, which itself is initialized from a climatological run with a 30-year spin up. The initial conditions for the climatological spin up are specified from the

90 WOA2013. We carry out an interannual simulation for the period of 1978-2000, and analyze model output for the period of 1981-2000. 


\subsection{Ocean biogeochemical model}

The dynamic marine ecosystem-carbon (DMEC) model is the main part of the biogeochemical model that is embedded in the basin-scale OGCM. The DMEC model consists of eleven components: small (S) and large (L) sizes of phytoplankton $\left(P_{S}\right.$ and $P_{L}$ ), zooplankton $\left(Z_{S}\right.$ and $\left.Z_{L}\right)$ and detritus $\left(D_{S}\right.$ and $\left.D_{L}\right)$, DON, ammonium, nitrate, dissolved iron, and DO (Figure 1). All biological components use nitrogen as their unit, and are computed in a manner similar to physical variables.

In this model, net community production (NCP) is computed as:

$$
N C P=6.625 *\left(\mu_{S} P_{S}+\mu_{L} P_{L}-r_{S} Z_{s}-r_{L} Z_{L}-c_{D O N} D O N-c_{D S} D_{S}-c_{D L} D_{L}\right)
$$

100 where 6.625 is the $\mathrm{C}: \mathrm{N}$ ratio, $\mu$ the rate of phytoplankton growth, $r$ the rate of zooplankton respiration, $c$ the rates of detritus decomposition and DON remineralization. The equations for biogeochemical processes and model parameters have been reported in details previously (Wang et al., 2008; Wang et al., 2015).

\subsection{Computation of oxygen sources and sinks}

The time evolution of DO is regulated by physical, biological and chemical processes:

$105 \frac{\partial O_{2}}{\partial t}=-u \frac{\partial O_{2}}{\partial x}-v \frac{\partial O_{2}}{\partial y}-w \frac{\partial O_{2}}{\partial z}+O_{\text {mix }}+O_{b i o}+O_{g a s}$

where $u, v$, and $w$ are zonal, meridional, and vertical velocity, respectively. $O_{m i x}$ is the vertical mixing term that is calculated by three subroutines (Chen et al., 1994). Briefly, the first one computes convection to remove instabilities in the water column, and the second one determines the mixed layer depth. The third one computes partial mixing $\left(\mathrm{P}_{\mathrm{m}}\right)$ between two adjacent layers to relieve gradient Richardson number instability, which is calculated as follows:

$110 P_{m}=\left(1-\left(\frac{R i}{0.7}\right)^{\lambda}\right)(R i \leq 0.7)$

$P_{m}=0(R i>0.7)$

where the mixing parameter $\lambda$ is set to 1 .

The biological source/sink term $O_{b i o}$ is computed as follows:

$115 O_{\text {bio }}=-1.3 * \mathrm{NCP}$

where 1.3 is the $\mathrm{O}: \mathrm{C}$ Redfield ratio.

The flux of $\mathrm{O}_{2}$ from the atmosphere to the surface ocean is computed as:

$O_{\text {gas }}=\left(O_{\text {Sat }}-O\right) K_{0}$

120 where $O_{s a t}$ is the $\mathrm{O}_{2}$ saturation, a function of temperature and salinity (Weiss, 1970), and $K_{0}$ the gas transfer velocity that is a function of wind speed $\left(u_{s}\right)$ and SST according to Wanninkhof (1992):

$K_{0}=0.31 u_{s}^{2} \sqrt{\frac{s c}{s c 20}}$ 
https://doi.org/10.5194/gmd-2020-105

Preprint. Discussion started: 29 July 2020

(c) Author(s) 2020. CC BY 4.0 License.

(c) (i)

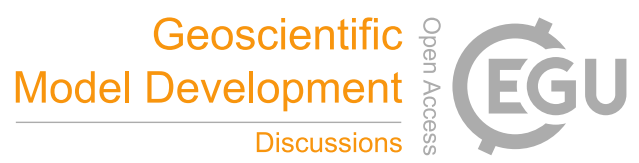

where $S c\left(S c_{20}\right)$ is the Schmidt number at SST (at $\left.20^{\circ} \mathrm{C}\right)$ :

$S_{c}=1953-128 T+3.99 T^{2}-0.05 T^{3}$

\section{3. Model evaluation and experiments}

\subsection{Evaluation of DO concentrations}

We first evaluate simulated DO for the tropical Pacific Ocean using the outputs from OGCM-DMEC V1.0 (hereafter reference run). We focus on model-data comparisons for the layers of 0-200 $\mathrm{m}$ and 200-600 $\mathrm{m}$ that broadly represent the euphotic zone and OMZ, respectively. For the 0-200 m, the observed large-scale spatial pattern of DO is captured by the reference run, both data and model output show the low DO waters $\left(<120 \mathrm{mmol} \mathrm{m}^{-3}\right)$ in the eastern tropical Pacific Ocean and supersaturated DO $\left(>200 \mathrm{mmol} \mathrm{m}^{-3}\right.$ ) in majority of other sections (Figure 2a and 2c). Overall, the bias from the reference run is very small $\left(<10 \mathrm{mmol} \mathrm{m}^{-3}\right)$ in the surface water (Figure 2e). For the mid-depth, the WOA2013 data shows much larger area of suboxic waters $\left(<20 \mathrm{mmol} \mathrm{m}^{-3}\right)$ in the ETNP than in the ETSP (Figure 2b). Although the reference run produces two OMZs off the equator (Figure 2d), the size of suboxic waters in the ETNP is much larger in the reference run than that in the

135 WOA2013 data. The reference run thus underestimates DO over 200-600 m, particularly in the eastern tropical Pacific, with a bias of $10-20 \mathrm{mmol} \mathrm{m}^{-3}$ (Figure $2 \mathrm{f}$ ). The relative roles of the physics vs. the biogeochemistry in determining the bias are diagnosed further below.

\subsection{Sensitive experiments}

140 The underestimated DO at mid-depth may be a result of overestimation of removal (primarily the consumption associated with remineralization of organic materials) and/or underestimation of supply (e.g., vertical mixing). We conduct a sensitivity study that consists of four new simulations. The first two experiments are designed to reduce the biological consumption of DO: by reducing DON remineralization constant $\left(c_{D O N}\right.$ in equation 1$)$ by $50 \%$ (Exp1), or changing O:C utilization ratio $\left(R_{O C}\right.$ in equation 5) from 1.3 to 1.0 (Exp2); the other two are to increase supply of DO by changing the partial mixing parameter

$145\left(P_{m}\right.$ in equation 4$)$ from 0 to $10^{-4} \mathrm{~m}^{-2} \mathrm{~s}^{-1}\left(\right.$ Exp3), or applying a variable $P_{m}$ (Table 1$)$.

The comparisons between simulated DO and WOA2013 climatology data are shown in Figure 3 and 4. Figure 3a illustrates the observed vertical-zonal variations of DO over $10^{\circ} \mathrm{S}-15^{\circ} \mathrm{N}$, showing small volume of suboxic water $\left(<20 \mathrm{mmol} \mathrm{m}^{-3}\right)$ centered at $\sim 400-600 \mathrm{~m}$ from $110^{\circ} \mathrm{W}$ to $90^{\circ} \mathrm{W}$. Similar to the reference run (Figure 3b), Exp1 and Exp2 also under-estimates DO concentration at mid-depth (Figure $3 \mathrm{c}$ and $3 \mathrm{~d}$ ), showing much larger volume of suboxic waters than that from WOA2013. On the other hand, Exp3 and Exp4 produce reasonable DO concentrations at mid-depth, particularly in the east 
of $120^{\circ} \mathrm{W}$ (Figure $3 \mathrm{e}$ and $3 \mathrm{f}$ ), although the simulated volume of suboxic water is slightly larger than from the observation data (Figure 3a).

155 Figure 4a illustrates a larger volume of suboxic water located north of $\sim 4^{\circ} \mathrm{N}$ and a smaller volume of suboxic water over $8^{\circ} \mathrm{S}-4^{\circ} \mathrm{S}$, which are separated by relatively higher DO $\left(>30 \mathrm{mmol} \mathrm{m}^{-3}\right)$ along the equator. Both Exp1 and Exp2 (Figure 4c and $4 \mathrm{~d}$ ), as well as the reference run (Figure $4 \mathrm{~b}$ ), produce much larger volumes of suboxic water that are extend to the equatorial region, and even merge into one. Exp3 and Exp4 (Figure 4e and 4f) capture the observed basin-scale spatial distribution of DO, particularly the asymmetric feature (i.e., a larger volume of suboxic water to the north but a smaller size of suboxic water to the south), and relatively higher DO $\left(\sim 40 \mathrm{mmol} \mathrm{m}^{-3}\right)$ over $4^{\circ} \mathrm{S}-2^{\circ} \mathrm{N}$. Many ESMs are unable to reproduce the positions and sizes of the OMZs in the eastern tropical Pacific Ocean (Bao and Li, 2016; Cabré et al., 2015); some models overestimated the extent of suboxic water, which might be due to over-estimated productivity in the euphotic zone (Moore et al., 2013; Williams et al., 2014).

\subsection{Model skill assessment}

To further evaluate the performance of experiments on OMZs, four statistical measures are applied over 300-500 $\mathrm{m}$ in the $\operatorname{ETNP}\left(150^{\circ} \mathrm{W}-90^{\circ} \mathrm{W}, 0^{\circ}-10^{\circ} \mathrm{N}\right)$ and $\operatorname{ETSP}\left(150^{\circ} \mathrm{W}-90^{\circ} \mathrm{W}, 10^{\circ} \mathrm{S}-0^{\circ}\right)$. As showed in Table 2 , compared to the reference run, both bias and RMSE decrease in all four experiments, with the smallest bias $\left(-8.59 \mathrm{mmol} \mathrm{m}^{-3}\right.$ in ETNP and $1.05 \mathrm{mmol} \mathrm{m}^{-3}$ in ETSP) and RMSE (12.36 mmol m $\mathrm{m}^{-3}$ in ETNP and $8.43 \mathrm{mmol} \mathrm{m}^{-3}$ in ETSP) found in Exp3. Many current models show a maximum of RMSE ( 20-80 $\mathrm{mmol} \mathrm{m}^{-3}$ ) with respect to observed DO from mixed layer to $1000 \mathrm{~m}$ (Bao and Li, 2016; Cabré et al., 2015). Table 1 and Figure 5 illustrate that Exp3 produces the best outputs, with the highest correlation coefficient (0.72 in ETNP and 0.893 in ETSP) and also close-to-1 NSD (1.03 in ETNP and 1.71 in ETSP).

\section{Results and discussions}

In this section, we further compare the improved model simulation (EXP3) and reference run to diagnose the relative contributions of physical supply and biological consumption to the asymmetric OMZs in the tropical Pacific, aiming to identify the underlying mechanisms regulating the dynamics of mid-depth DO.

\subsection{Distribution of DO and physical supple at mid-depth}

We first compare the distribution of DO over 300-500 m between reference run and Exp3. The reference run produces much

180 large volume of suboxic waters $\left(<20 \mathrm{mmol} \mathrm{m}^{-3}\right)$ in both the ETNP and ETSP where the two OMZs are merged (Figure 6a). On the other hand, Exp3 performs well in reproducing the sizes and locations of two asymmetric OMZs (Figure 6b). Mid- 
depth DO concentration is 1-20 $\mathrm{mmol} \mathrm{m}^{-3}$ higher in the Exp3 than in the reference run, with the largest difference in the western equatorial Pacific (Figure 6c). However, despite of the small absolute increase (1-5 $\left.\mathrm{mmol} \mathrm{m}^{-3}\right)$ in the ETNP, the relative increase of DO is approximately 200-400\%, indicating that mid-depth DO in the north OMZ is more sensitive to the parameterization of physical processes.

The overall increased DO at mid-depth is likely a result of stronger physical supply, as seen below, due to enhanced background diffusion in Exp3. Numerous studies have indicated that physical mixing is the only source of DO for OMZs (Brandt et al., 2015; Czeschel et al., 2012; Talley et al., 2016), particularly, turbulent diffusion accounted for 89\% of the net DO supply for the core OMZ layer (Llanillo et al., 2018). The reference run in our study shows a range of 4-11 $\mathrm{mmol} \mathrm{m}^{-3} \mathrm{yr}^{-}$

${ }^{1}$ in physical supply over the $300-500 \mathrm{~m}$, with higher rates $\left(>11 \mathrm{mmol} \mathrm{m}^{-3} \mathrm{yr}^{-1}\right)$ found mainly in the northern central tropical Pacific, which is located inside of the suboxic waters (Figure 7a). Exp3 produces generally higher rates (5-12 $\left.\mathrm{mmol} \mathrm{m}^{-3} \mathrm{yr}^{-1}\right)$ of physical supply, with a larger size of high-rate $\left(>11 \mathrm{mmol} \mathrm{m}^{-3} \mathrm{yr}^{-1}\right)$ water near the edge of northern suboxic water (Figure $7 \mathrm{~b})$. There have been a handful of modelling studies of physical supply rate for the mid-depth waters of tropical Pacific, which show similar magnitudes (from $\sim 4$ to $\sim 8 \mathrm{mmol} \mathrm{m}^{-3} \mathrm{yr}^{-1}$ ) (Llanillo et al., 2018; Shigemitsu et al., 2017). Figure 7c illustrates that physical supply is increased by $\sim 0.5-1 \mathrm{mmol} \mathrm{m}^{-3} \mathrm{yr}^{-1}$ in most of the mid-depth, with the highest increase in the southern part of central equatorial Pacific. Interestingly, there is somehow a small decrease (by $\sim 0.1 \mathrm{mmol} \mathrm{m}^{-3} \mathrm{yr}^{-1}$ ) of physical supply in the ETNP-OMZ, implying that changes in other processes such as biological consumption may also contribute to the enhanced DO at mid-depth.

\subsection{Biological consumption of DO at mid-depth}

We further compare biological consumption of DO between Exp3 and the reference run (Figure 8). For the reference run, biological consumption rate is $<6 \mathrm{mmol} \mathrm{m}^{-3} \mathrm{yr}^{-1}$ off the equator and $>10 \mathrm{mmol} \mathrm{m}^{-3} \mathrm{yr}^{-1}$ in most of the upwelling region, with higher rates (>11 mmol m $\left.\mathrm{yr}^{-1}\right)$ mainly located in the northern central tropical Pacific, and in the suboxic waters (Figure 8a). Clearly, Exp3 produces lower rates of biological consumption in the entire basin, showing smaller size of $>11 \mathrm{mmol} \mathrm{m}^{-3} \mathrm{yr}^{-1}$ relative to the reference run, which is located on the southern edge of northern suboxic waters (Figure 8b). Limited modelling studies reported slightly lower rates $\left(<5 \mathrm{mmol} \mathrm{m}^{-3} \mathrm{yr}^{-1}\right)$ in the mid-waters of tropical Pacific (Llanillo et al., 2018; Shigemitsu et al., 2017). The decrease in biological consumption ranges from $\sim 0.1$ to $0.3 \mathrm{mmol} \mathrm{m}^{-3} \mathrm{yr}^{-1}$ (Figure $8 \mathrm{c}$ ). For the northern OMZ, biological consumption decreases by $\sim 0.15-0.2 \mathrm{mmol} \mathrm{m}^{-3} \mathrm{yr}^{-1}$, which is greater than the decreased rate $(\sim 0.1$ $\mathrm{mmol} \mathrm{m} \mathrm{mr}^{-1}$ ) of physical supply (see Figure 7c).

Biological consumption of DO in the mid-depth water largely results from remineralization of dissolved organic matter (DOM) and decomposition of particulate organic matter (POM). The reference run simulates a range of $\sim 6-12 \mathrm{mmol} \mathrm{m}^{-3} \mathrm{yr}^{-1}$ and $~ 0.6-1.5 \mathrm{mmol} \mathrm{m}^{-3} \mathrm{yr}^{-1}$ for DOM remineralization and POM decomposition, respectively, with the largest values inside 
215 of the suboxic waters (Figure 9a and 9b). Clearly, Exp3 produces lower rates for both DOM remineralization and POM decomposition over the entire basin (Figure $9 \mathrm{c}$ and $9 \mathrm{~d}$ ), with a decrease of $\sim 0.1-0.2 \mathrm{mmol} \mathrm{m}^{-3} \mathrm{yr}^{-1}$ and $\sim 0.01-0.02 \mathrm{mmol} \mathrm{m}^{-3}$ $\mathrm{yr}^{-1}$, respectively (Figure 9e and 9f). Apparently, the consumption rate contributed by remineralization of DOM is much greater than that by decomposition of POM at mid-depth, indicating that remineralization of DOM is the dominant process consuming DO at mid-depth. Many other studies also illustrated that the extent of OMZs was not only sensitive to physical mixing but also to remineralization of DOM (Kriest et al., 2010; Loginova et al., 2019).

\subsection{Spatial variations of DOM and its remineralization rate}

Remineralization rate of DOM in the ocean is determined by the size of DOM pool and temperature (Brewer and Peltzer, 2016; Wang et al., 2008). Given that there is little difference $\left(<10^{-5}{ }^{\circ} \mathrm{C}\right)$ in seawater temperature between different model experiments, the reduced consumption rates due to DOM remineralization would be a result of a smaller size of DOM. Here, we evaluate the zonal and meridional distributions distribution of dissolved organic nitrogen (DON) together with remineralization rate of DON. As shown in Figure 10a-10d, modelled DON decreases from 6-8 $\mathrm{mmol} \mathrm{N} \mathrm{m}^{-3}$ near the surface to 2-4 mmol N m${ }^{-3}$ over 400-1000 m. Notably, our modelled remineralization rate of DON decreases from $\sim 20 \mathrm{mmol} \mathrm{m}^{-3} \mathrm{yr}^{-1}$ in the euphotic zone to $\sim 4-8 \mathrm{mmol} \mathrm{m}^{-3} \mathrm{yr}^{-1}$ below $400 \mathrm{~m}$, which is similar to the vertical variation of DON. Enhanced background diffusion leads to a decrease in DON concentration (up to $0.2 \mathrm{mmol} \mathrm{N} \mathrm{m}{ }^{-3}$ ) over $300-900 \mathrm{~m}$, but an increase below $1000 \mathrm{~m}$ in the eastern tropical Pacific (Figure 10e and 10f).

Our previous study showed that the basin-scale model reproduced observed meridional distribution of surface DON (fall 1992) in the eastern tropical Pacific (Wang et al., 2008). A recent field study reported that surface DON concentration was

5-7 $\mathrm{mmol} \mathrm{N} \mathrm{m}^{-3}$ in the ETSP (Loginova et al., 2019), which is similar to our model results. While there was little information on measured rates of DOM remineralization and oxygen consumption at mid-depth of tropical Pacific, there were some field studies conducted in other ocean/sections (e.g., subtropical Atlantic and North Pacific), which showed comparable or slightly lower rates of oxygen consumption (Sonnerup et al., 2013; Stanley et al., 2012). For instance, cruise data within the subtropical North Pacific showed that consumption rate ranged from $8.3 \mathrm{mmol} \mathrm{m}^{-3} \mathrm{yr}^{-1}$ at $\sim 200 \mathrm{~m}$ to $<3.1$ mmol m${ }^{-3} \mathrm{yr}^{-1}$ below $500 \mathrm{~m}$ (Sonnerup et al., 2013).

\subsection{Impacts of physical supply and biological consumption on asymmetry of OMZs}

Previous studies have demonstrated meridional asymmetric features in many physical and biological fields in the tropical Pacific, e.g., temperature and salinity (Fiedler and Talley, 2006), circulation and ventilation (Kessler, 2006; Kuntz and Schrag, 2018), nitrogen and carbon cycles (Libby and Wheeler, 1997; Wang et al., 2009), which may be largely associated 
Accordingly, one may assume that the hemisphere asymmetry of OMZs could be related to the differences in physical supply and biological consumption between the ETNP and ETSP.

While the dynamics of the tropical Pacific's OMZ is sensitive to changes in ocean circulation (Czeschel et al., 2011; Montes et al., 2014; Stramma et al., 2010), small scale processes such as background diffusion also have a significant influence on the supply of DO into the core OMZ and the mean state of DO distribution (Duteil and Oschlies, 2011; Getzlaff and Dietze, 2013; Llanillo et al., 2018). Clearly, our model experiment shows that enhanced background diffusion leads to a significant increase in DO concentration below $200 \mathrm{~m}$ (Figure 11a). The increase of DO is similar below $600 \mathrm{~m}$ in the ETNP and ETSP, but differs largely between the two regions, with much greater values over 200-600 $\mathrm{m}$ in the ETSP.

Recent studies have emphasized the role of changes in physical processes for the observed asymmetric OMZs in the tropical oceans. For instance, larger-scale mass transport related to circulation and ventilation in the southern hemisphere is more efficient than in the northern hemisphere (Kuntz and Schrag, 2018), and the transit time from the surface to the OMZ is much longer in the ETNP than in the ETSP (Fu et al., 2018; Sonnerup et al., 2013). Our study shows that enhanced background diffusion increases the physical supply of DO over most of the water column, with significant increases $(>0.4$ mmol m $\mathrm{m}^{-3} \mathrm{yr}^{-1}$ ) below $200 \mathrm{~m}$ in the ETSP (Figure 11b). However, the ETNP shows a much smaller increase in physical supply, particular over $\sim 300-700 \mathrm{~m}\left(<0.2 \mathrm{mmol} \mathrm{m}^{-3} \mathrm{yr}^{-1}\right)$ (Figure 11a), indicating that physical supply may be largely responsible for the asymmetry of OMZs. On the other hand, increased DO is greatest at $\sim 700 \mathrm{~m}$ in the ETNP (Figure 11a), which cannot be explained by the small increase in physical supply $\left(<0.4 \mathrm{mmol} \mathrm{m}^{-3} \mathrm{yr}^{-1}\right)$, implying that biological consumption may also play a role in regulating the dynamics of mid-depth DO.

There is evidence that the size of tropical OMZs is largely influenced by biological processes, such as organic matter export, remineralization and oxygen consumption (Cavan et al., 2017; Keller et al., 2016). Our further analyses demonstrate that biological consumption generally decreases in majority of the water column under enhanced background diffusion, with the largest decrease $\left(\sim 0.6-0.8 \mathrm{mmol} \mathrm{m}^{-3} \mathrm{yr}^{-1}\right)$ over $\sim 600-800 \mathrm{~m}$ (Figure $\left.11 \mathrm{c}\right)$, which is greater than the increased rate $(\sim 0.3-0.5$ $\mathrm{mmol} \mathrm{m} \mathrm{mr}^{-1}$ ) of physical supply (Figure 11b). Enhanced background diffusion leads to remarkable decrease of DON over $\sim 300-900 \mathrm{~m}$, with a larger decrease in the ETNP (Figure 11d). Earlier field studies revealed that DON concentration in the euphotic zone is much higher to the north than to the south in the central-eastern tropical Pacific (Libby and Wheeler, 1997; Raimbault et al., 1999). Later studies showed that rates of DOM remineralization and oxygen consumption are also greater at mid-depth in the ETNP than in the ETSP (Feely et al., 2004; Kalvelage et al., 2015; Tiano et al., 2014). Apparently, the asymmetric OMZs in the tropical Pacific are attributed to not only physical processes, but also biological processes. 
https://doi.org/10.5194/gmd-2020-105

Preprint. Discussion started: 29 July 2020

(c) Author(s) 2020. CC BY 4.0 License.

(c) (1)

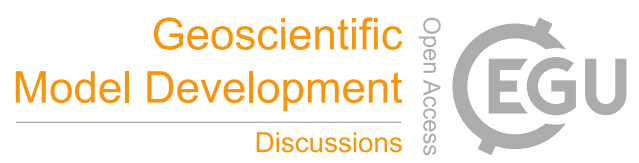

\section{Conclusion}

This paper describes an evaluation and validation of a fully coupled basin-scale model (OGCM-DMEC V1.0), focusing on the sensitivity of the asymmetric OMZs in the tropical Pacific to different parameterizations. Our results show that the improved model with enhanced background diffusion successfully reproduces the observed asymmetric OMZs in tropical Pacific, indicating that distribution of DO at mid-depth is more sensitive to physical mixing (e.g., enhanced background diffusion) rather than biological processes (e.g., reduced DO utilization rate).

Our analyses suggest that DO concentration at mid-depth is significantly increased due to enhanced background diffusion, resulting from changes in both physical supply and biological consumption. On the one hand, physical supply of DO is largely increased in the majority of the tropical Pacific, but shows little change at mid-depth in the ETNP. On the other hand, biological consumption shows a significant decline over 300-1000 m and an increase below $1000 \mathrm{~m}$, as a result of the redistribution of DOM in the water column.

Our further analyses demonstrate that the asymmetric OMZs in the tropical Pacific are largely associated with asymmetry in both physical supply and biological consumption. In particular, physical supply plays a dominant role for the asymmetry of core OMZs ( 200-600 m) while biological consumption has impacts on the asymmetric DO below the OMZs, with implications for the hemisphere asymmetric OMZs. Future studies should consider both physical and biological aspects to 295 deliver comprehensive assessments on the interactions between DO and DOM, which is critical for a better understanding of variability and drivers of the tropical asymmetric OMZs. 
https://doi.org/10.5194/gmd-2020-105

Preprint. Discussion started: 29 July 2020

(c) Author(s) 2020. CC BY 4.0 License.

(c) (1)

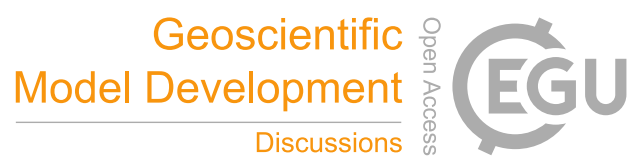

Code and data availability. The exact version of the software code used to produce the results presented in this paper is

300 archived on Zenodo (http://doi.org/10.5281/zenodo.3890689, Wang et al., 2020). Other code and data are available upon request from the authors. Request for materials should be addressed to X.J.W. (xwang@bnu.edu.cn).

Author contributions. X.J.W. and K.W. designed the study, performed the simulations and prepared the manuscript. R.M., D.X.Z. and R.H.Z. contributed to analysis, interpretation of results and writing.

305

Competing interests. The authors declare that they have no conflict of interest.

Acknowledgements. This work was supported by the Chinese Academy of Sciences' Strategic Priority Project (XDA1101010504). The authors wish to acknowledge the use of the Ferret (http://ferret.pmel.noaa.gov/Ferret/). 
https://doi.org/10.5194/gmd-2020-105

Preprint. Discussion started: 29 July 2020

(c) Author(s) 2020. CC BY 4.0 License.

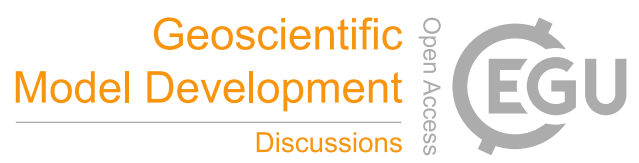

\section{References}

Bao, Y. and Li, Y.: Simulations of dissolved oxygen concentration in CMIP5 Earth system models, Acta Oceanologica Sinica, 35, 28-37, 2016.

315 Bopp, L., Le Quéré, C., Heimann, M., Manning, A. C., and Monfray, P.: Climate-induced oceanic oxygen fluxes: Implications for the contemporary carbon budget, Global Biogeochemical Cycles, 16, 1-13, 2002.

Brandt, P., Bange, H. W., Banyte, D., Dengler, M., Didwischus, S. H., Fischer, T., Greatbatch, R. J., Hahn, J., Kanzow, T., Karstensen, J., Krortzinger, A., Krahmann, G., Schmidtko, S., Stramma, L., Tanhua, T., and Visbeck, M.: On the role of circulation and mixing in the ventilation of oxygen minimum zones with a focus on the eastern tropical North Atlantic,

320 Biogeosciences, 12, 489-512, 2015.

Breitburg, D., Levin, L. A., Oschlies, A., Gregoire, M., Chavez, F. P., Conley, D. J., Garcon, V., Gilbert, D., Gutierrez, D., Isensee, K., Jacinto, G. S., Limburg, K. E., Montes, I., Naqvi, S. W. A., Pitcher, G. C., Rabalais, N. N., Roman, M. R., Rose, K. A., Seibel, B. A., Telszewski, M., Yasuhara, M., and Zhang, J.: Declining oxygen in the global ocean and coastal waters, Science, 359, 2018.

325 Brewer, P. G. and Peltzer, E. T.: Ocean chemistry, ocean warming, and emerging hypoxia: Commentary, Journal of Geophysical Research: Oceans, 121, 3659-3667, 2016.

Cabré, A., Marinov, I., Bernardello, R., and Bianchi, D.: Oxygen minimum zones in the tropical Pacific across CMIP5 models: mean state differences and climate change trends, Biogeosciences, 12, 5429-5454, 2015.

Cavan, E. L., Trimmer, M., Shelley, F., and Sanders, R.: Remineralization of particulate organic carbon in an ocean oxygen

330 minimum zone, Nature communications, 8, 14847, 2017.

Chen, D., Rothstein, L. M., and Busalacchi, A. J.: A hybrid vertical mixing scheme and its application to tropical ocean models, Journal of Physical Oceanography, 24, 2156-2179, 1994.

Czeschel, R., Stramma, L., and Johnson, G. C.: Oxygen decreases and variability in the eastern equatorial Pacific, Journal of Geophysical Research: Oceans, 117, 1-12, 2012.

335 Deutsch, C., Emerson, S., and Thompson, L.: Physical-biological interactions in North Pacific oxygen variability, Journal of Geophysical Research: Oceans, 111, 2006.

Fiedler, P. C. and Talley, L. D.: Hydrography of the eastern tropical Pacific: A review, Progress in Oceanography, 69, 143 $180,2006$.

Fu, W. W., Bardin, A., and Primeau, F.: Tracing ventilation source of tropical pacific oxygen minimum zones with an

340 adjoint global ocean transport model, Deep-Sea Research Part I: Oceanographic Research Papers, 139, 95-103, 2018. Garçon, V., Karstensen, J., Palacz, A., Telszewski, M., Aparco Lara, T., Breitburg, D., Chavez, F., Coelho, P., CornejoD’Ottone, M., Santos, C., Fiedler, B., Gallo, N. D., Grégoire, M., Gutierrez, D., Hernandez-Ayon, M., Isensee, K., Koslow, T., Levin, L., Marsac, F., Maske, H., Mbaye, B. C., Montes, I., Naqvi, W., Pearlman, J., Pinto, E., Pitcher, G., Pizarro, O., Rose, K., Shenoy, D., Van der Plas, A., Vito, M. R., and Weng, K.: Multidisciplinary Observing in the World Ocean's

345 Oxygen Minimum Zone Regions: From Climate to Fish — The VOICE Initiative, Frontiers in Marine Science, 6, 2019. Gilly, W. F., Beman, J. M., Litvin, S. Y., and Robison, B. H.: Oceanographic and biological effects of shoaling of the oxygen minimum zone, Annual review of marine science, 5, 393-420, 2013.

Ito, T., Long, M. C., Deutsch, C., Minobe, S., and Sun, D. X.: Mechanisms of low-frequency oxygen variability in the North Pacific, Global Biogeochemical Cycles, 33, 110-124, 2019.

350 Kalnay, E., Kanamitsu, M., Kistler, R., Collins, W., Deaven, D., Gandin, L., Iredell, M., Saha, S., White, G., Woollen, J., Zhu, Y., Chelliah, M., Ebisuzaki, W., Higgins, W., Janowiak, J., Mo, K. C., Ropelewski, C., Wang, J., Leetmaa, A., Reynolds, R., Jenne, R., and Joseph, D.: The NCEP/NCAR 40-year reanalysis project, B Am Meteorol Soc, 77, 437-471, 1996.

Kalvelage, T., Lavik, G., Jensen, M. M., Revsbech, N. P., Loscher, C., Schunck, H., Desai, D. K., Hauss, H., Kiko, R.,

355 Holtappels, M., LaRoche, J., Schmitz, R. A., Graco, M. I., and Kuypers, M. M.: Aerobic microbial respiration In oceanic oxygen minimum zones, PloS one, 10, 2015.

Karstensen, J., Stramma, L., and Visbeck, M.: Oxygen minimum zones in the eastern tropical Atlantic and Pacific oceans, Progress in Oceanography, 77, 331-350, 2008.

Keller, D. P., Kriest, I., Koeve, W., and Oschlies, A.: Southern Ocean biological impacts on global ocean oxygen,

Geophysical Research Letters, 43, 6469-6477, 2016. 
https://doi.org/10.5194/gmd-2020-105

Preprint. Discussion started: 29 July 2020

(c) Author(s) 2020. CC BY 4.0 License.

Kessler, W. S.: The circulation of the eastern tropical Pacific: A review, Progress in Oceanography, 69, 181-217, 2006. Kriest, I., Khatiwala, S., and Oschlies, A.: Towards an assessment of simple global marine biogeochemical models of different complexity, Progress in Oceanography, 86, 337-360, 2010.

Kug, J. S., Kang, I. S., and An, S. I.: Symmetric and antisymmetric mass exchanges between the equatorial and offequatorial Pacific associated with ENSO, Journal of Geophysical Research: Oceans, 108, 2003.

Kuntz, L. B. and Schrag, D. P.: Hemispheric asymmetry in the ventilated thermocline of the Tropical Pacific, Journal of Climate 31, 1281-1288, 2018.

Levin, L. A.: Manifestation, drivers, and emergence of open ocean deoxygenation, Annual review of marine science, 10, 229-260, 2018.

370 Libby, P. S. and Wheeler, P. A.: Particulate and dissolved organic nitrogen in the central and eastern equatorial Pacific, Deep-Sea Research Part I: Oceanographic Research Papers, 44, 345-361, 1997.

Llanillo, P. J., Pelegri, J. L., Talley, L. D., Pena-Izquierdo, J., and Cordero, R. R.: Oxygen Pathways and Budget for the Eastern South Pacific Oxygen Minimum Zone, Journal of Geophysical Research: Oceans, 123, 1722-1744, 2018.

Loginova, A. N., Thomsen, S., Dengler, M., Ludke, J., and Engel, A.: Diapycnal dissolved organic matter supply into the

375 upper Peruvian oxycline, Biogeosciences, 16, 2033-2047, 2019.

Montes, I., Dewitte, B., Gutknecht, E., Paulmier, A., Dadou, I., Oschlies, A., and Garcon, V.: High-resolutionmodeling of the Eastern Tropical Pacific oxygen minimum zone: Sensitivity to the tropical oceanic circulation, Journal of Geophysical Research: Oceans, 119, 5515-5532, 2014.

Moore, J. K., Lindsay, K., Doney, S. C., Long, M. C., and Misumi, K.: Marine Ecosystem Dynamics and Biogeochemical

380 Cycling in the Community Earth System Model [CESM1(BGC)]: Comparison of the 1990s with the 2090s under the RCP4.5 and RCP8.5 Scenarios, Journal of Climate, 26, 9291-9312, 2013.

Murtugudde, R., Seager, R., and Busalacchi, A.: Simulation of the tropical oceans with an ocean GCM coupled to an atmospheric mixed-layer model, Journal of Climate, 9, 1795-1815, 1996.

Oschlies, A., Brandt, P., Stramma, L., and Schmidtko, S.: Drivers and mechanisms of ocean deoxygenation, Nature

385 Geoscience, 11, 467-473, 2018.

Palter, J. B. and Trossman, A. D. S.: The sensitivity of future ocean oxygen to changes in ocean circulation, Global

Biogeochemical Cycles, 32, 738-751, 2018.

Paulmier, A. and Ruiz-Pino, D.: Oxygen minimum zones (OMZs) in the modern ocean, Progress in Oceanography, 80, 113$128,2009$.

390 Raimbault, P., Slawyk, G., Boudjellal, B., Coatanoan, C., Conan, P., Coste, B., Garcia, N., Moutin, T., and Pujo-Pay, M.: Carbon and nitrogen uptake and export in the equatorial Pacific at $150^{\circ} \mathrm{W}$ : Evidence of an efficient regenerated production cycle, Journal of Geophysical Research: Oceans, 104, 3341-3356, 1999.

Schmidtko, S., Stramma, L., and Visbeck, M.: Decline in global oceanic oxygen content during the past five decades, Nature, 542, 335-339, 2017.

395 Shigemitsu, M., Yamamoto, A., Oka, A., and Yamanaka, Y.: One possible uncertainty in CMIP5 projections of low-oxygen water volume in the Eastern Tropical Pacifi, Geophysical Research Letters, 31, 804-820, 2017.

Sonnerup, R. E., Mecking, S., and Bullister, J. L.: Transit time distributions and oxygen utilization rates in the Northeast Pacific Ocean from chlorofluorocarbons and sulfur hexafluoride, Deep-Sea Research Part I: Oceanographic Research Papers, $72,61-71,2013$

400 Stanley, R. H. R., Doney, S. C., Jenkins, W. J., and Lott, I. D. E.: Apparent oxygen utilization rates calculated from tritium and helium-3 profiles at the Bermuda Atlantic Time-series Study site, Biogeosciences, 9, 1969-1983, 2012.

Stramma, L., Johnson, G. C., Firing, E., and Schmidtko, S.: Eastern Pacific oxygen minimum zones: Supply paths and multidecadal changes, Journal of Geophysical Research: Oceans, 115, 2010.

Stramma, L., Johnson, G. C., Sprintall, J., and Mohrholz, V.: Expanding oxygen-minimum zones in the tropical oceans,

405 Science, 320, 655-658, 2008.

Stramma, L., Oschlies, A., and Schmidtko, S.: Mismatch between observed and modeled trends in dissolved upper-ocean oxygen over the last $50 \mathrm{yr}$, Biogeosciences, 9, 4045-4057, 2012.

Talley, L. D., Feely, R. A., Sloyan, B. M., Wanninkhof, R., Baringer, M. O., Bullister, J. L., Carlson, C. A., Doney, S. C., Fine, R. A., Firing, E., Gruber, N., Hansell, D. A., Ishii, M., Johnson, G. C., Katsumata, K., Key, R. M., Kramp, M.,

410 Langdon, C., Macdonald, A. M., Mathis, J. T., McDonagh, E. L., Mecking, S., Millero, F. J., Mordy, C. W., Nakano, T., 
https://doi.org/10.5194/gmd-2020-105

Preprint. Discussion started: 29 July 2020

(c) Author(s) 2020. CC BY 4.0 License.

Sabine, C. L., Smethie, W. M., Swift, J. H., Tanhua, T., Thurnherr, A. M., Warner, M. J., and Zhang, J. Z.: Changes in ocean heat, carbon content, and ventilation: a review of the first decade of go-ship global repeat hydrography, Annual review of marine science, 8, 185-215, 2016.

Wang, X. J., Le Borgne, R., Murtugudde, R., Busalacchi, A. J., and Behrenfeld, M.: Spatial and temporal variations in

415 dissolved and particulate organic nitrogen in the equatorial Pacific: biological and physical influences, Biogeosciences, 5, 1705-1721, 2008.

Wang, X. J., Murtugudde, R., Hackert, E., Wang, J., and Beauchamp, J.: Seasonal to decadal variations of sea surface pCO2 and sea-air CO2 flux in the equatorial oceans over 1984-2013: A basin-scale comparison of the Pacific and Atlantic Oceans, Global Biogeochemical Cycles, 29, 597-609, 2015.

420 Wang, X. J., Murtugudde, R., and Le Borgne, R.: Nitrogen uptake and regeneration pathways in the equatorial Pacific: a basin scale modeling study, Biogeosciences, 6, 2647-2660, 2009.

Wanninkhof, R.: Relationship between wind speed and gas exchange over the Ocean, Journal of Geophysical Research, 97, 7373-7382, 1992.

Ward, B. A., Wilson, J. D., Death, R. M., Monteiro, F. M., Yool, A., and Ridgwell, A.: EcoGEnIE 1.0: plankton ecology in the cGEnIE Earth system model, Geoscientific Model Development, 11, 4241-4267, 2018.

Weiss, R. F.: The solubility of nitrogen, oxygen and argon in water and seawater, Deep-Sea Research, 17, 721-735, 1970.

Williams, J. H. T., Totterdell, I. J., Halloran, P. R., and Valdes, P. J.: Numerical simulations of oceanic oxygen cycling in the FAMOUS Earth-System model: FAMOUS-ES, version 1.0, Geoscientific Model Development, 7, 1419-1431, 2014. 


\section{Figures}

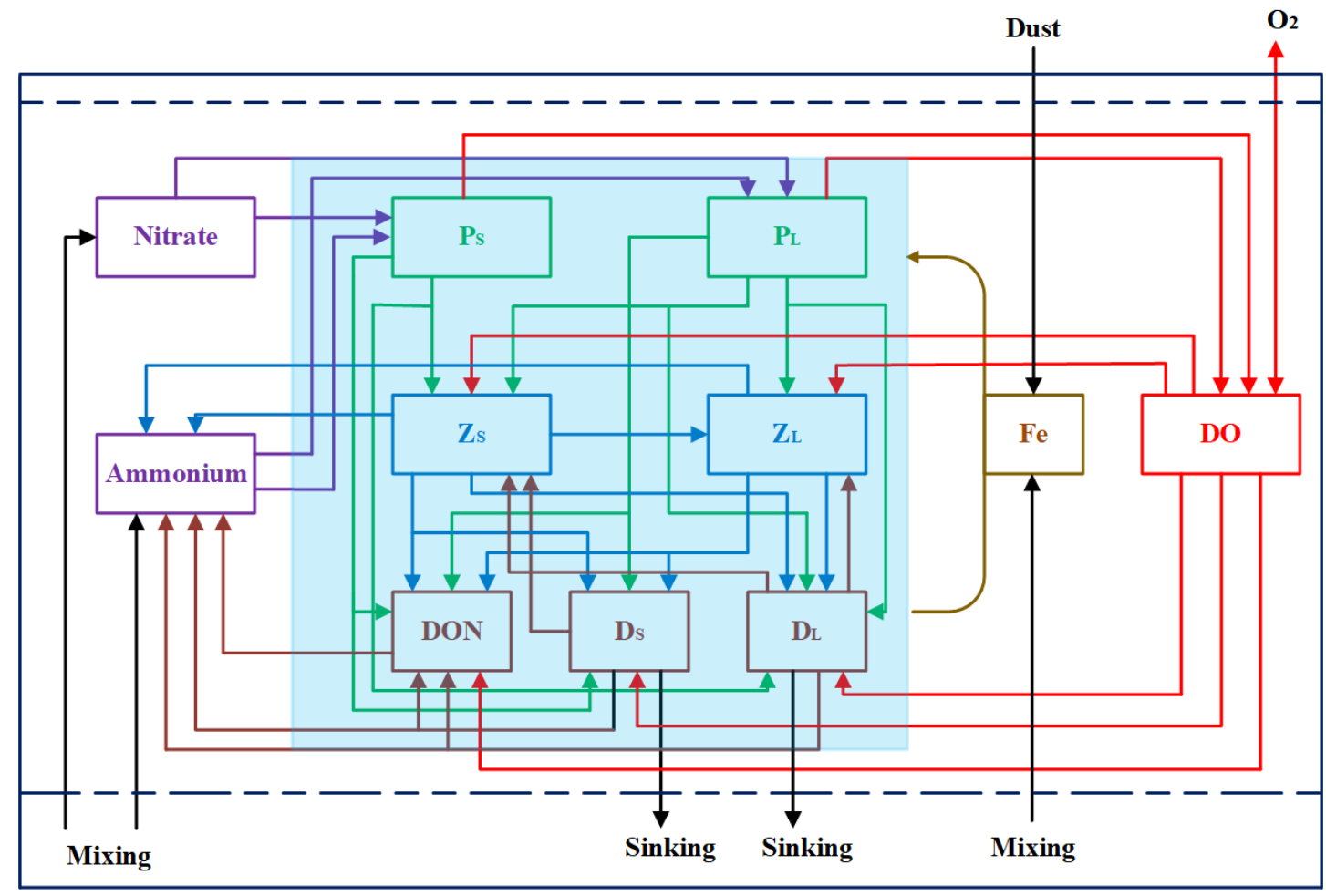

Figure 1. Flow diagram of ecosystem model. Red lines and arrows denote oxygen sources and sinks. Purple, green, blue and brown lines and arrows denote fluxes originating from inorganic forms, phytoplankton, zooplankton, and DON and detritus, respectively. 
https://doi.org/10.5194/gmd-2020-105

Preprint. Discussion started: 29 July 2020

(c) Author(s) 2020. CC BY 4.0 License.

(a) WOA2013

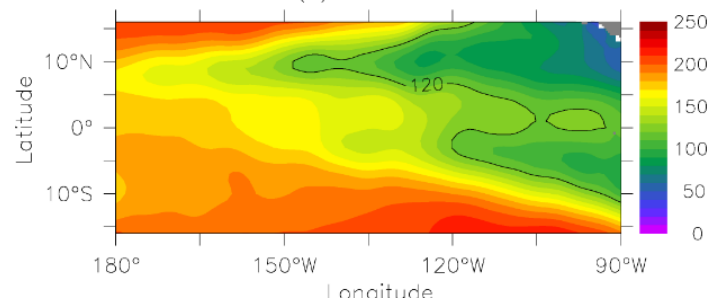

(c) Ref

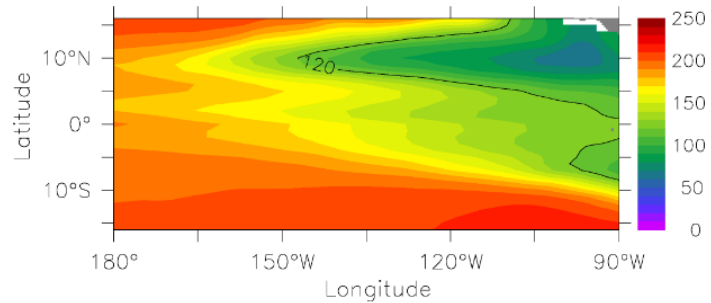

(e) Ref - WOA2013

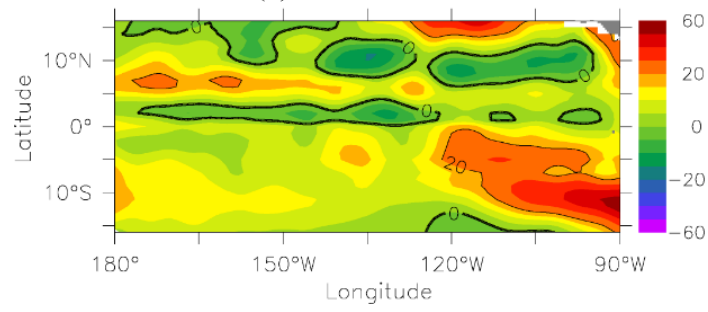

(b) WOA2013

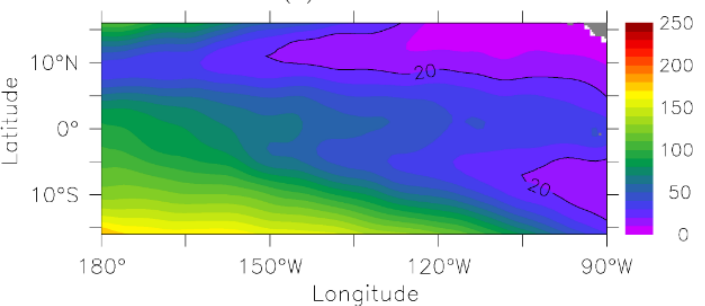

(d) Ref

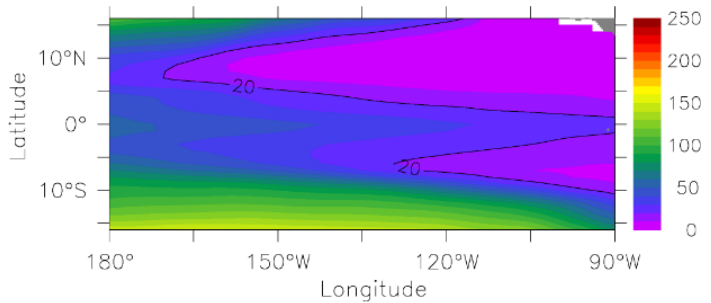

(f) Ref - WOA2013

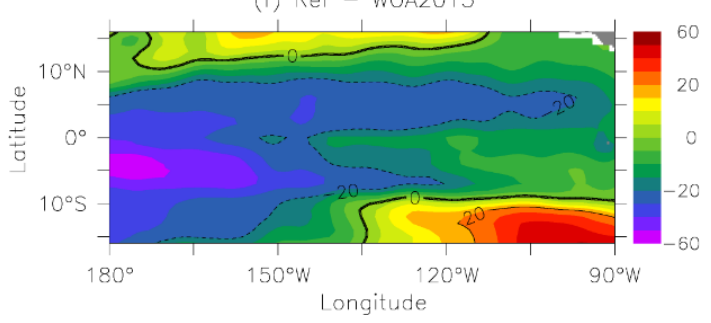

Figure 2. Observed and simulated DO concentrations $\left(\mathrm{mmol} \mathrm{m}^{-3}\right)$ and the differences over 0-200 $\mathrm{m}$ (left panel) and 200-600 $\mathrm{m}$ (right panel). (a) and (b) WOA2013 data, (c) and (d) reference run for the period of 1981-2000, and (e) and (f) the difference of DO between model and data. Superimposed black lines denote the borders of low-DO water $\left(<120 \mathrm{mmol} \mathrm{m}^{-3}\right)$ in (a) and (c), and suboxic water $(<20$

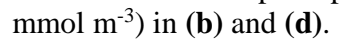


https://doi.org/10.5194/gmd-2020-105

Preprint. Discussion started: 29 July 2020

(c) Author(s) 2020. CC BY 4.0 License.

\section{(c) (i)}
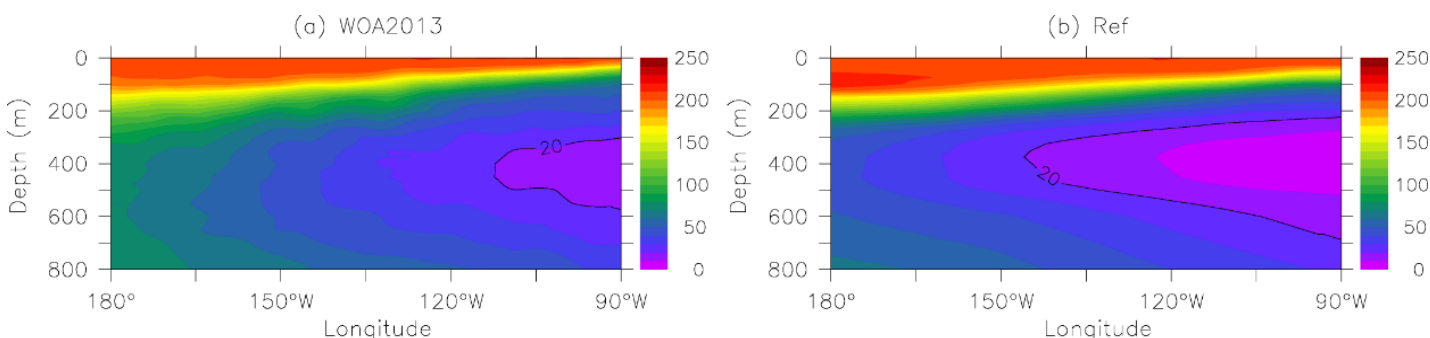

(c) $\operatorname{Exp} 1$
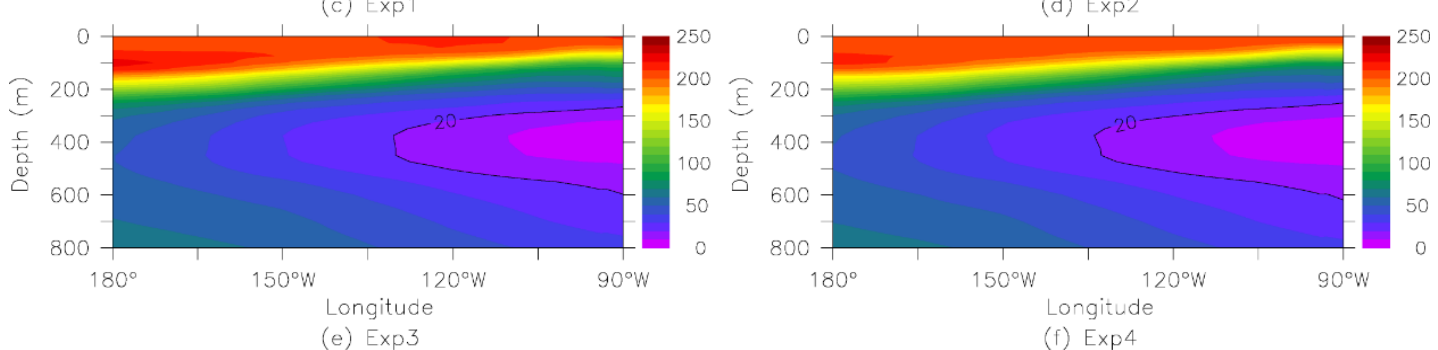

(e) Exp3
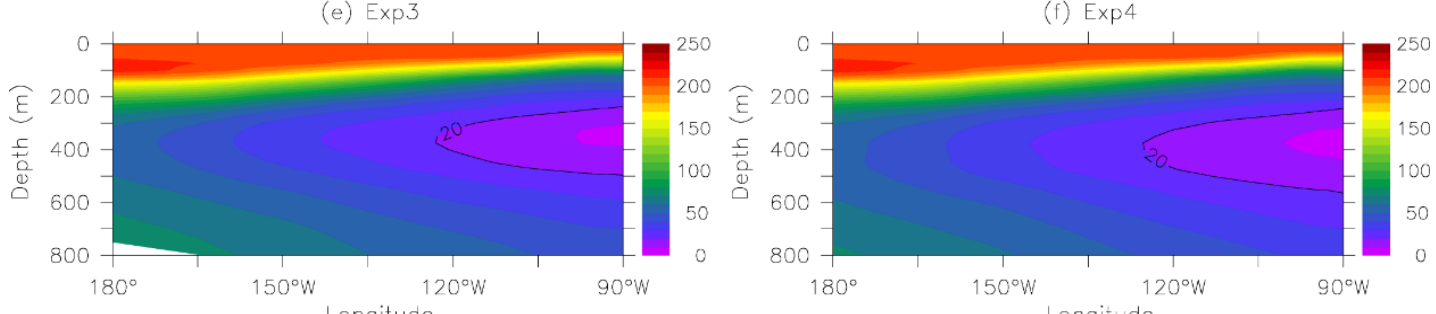

Figure 3. Observed and simulated mean DO concentrations $\left(\mathrm{mmol} \mathrm{m}^{-3}\right)$ from sensitivity experiments over $10^{\circ} \mathrm{S}-15^{\circ} \mathrm{N}$. (a) WOA2013 data, (b) reference run, (c) Exp1, (d) Exp2, (e) Exp3, and (f) Exp4 for the period of 1981-2000. Superimposed black lines denote the borders of suboxic water $\left(<20 \mathrm{mmol} \mathrm{m}^{-3}\right)$ in $(\mathbf{a}-\mathbf{f})$. 
https://doi.org/10.5194/gmd-2020-105

Preprint. Discussion started: 29 July 2020

(c) Author(s) 2020. CC BY 4.0 License.

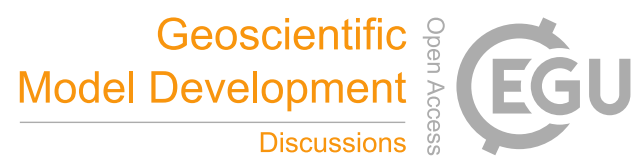

(c) ${ }_{\mathrm{BY}}$

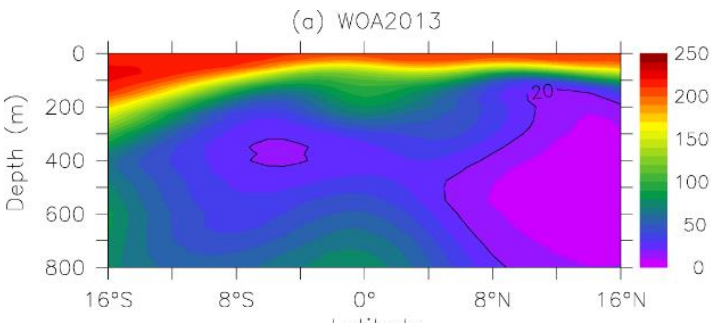

(c) Exp1

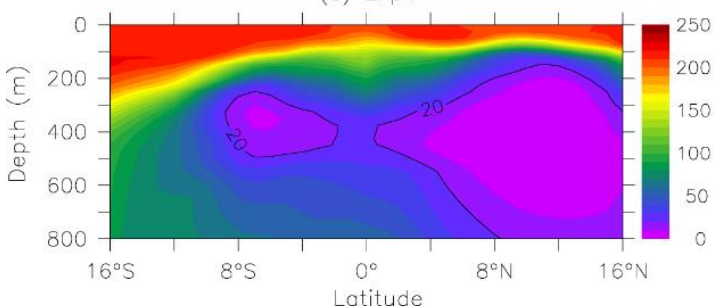

(e) $\operatorname{Exp} 3$
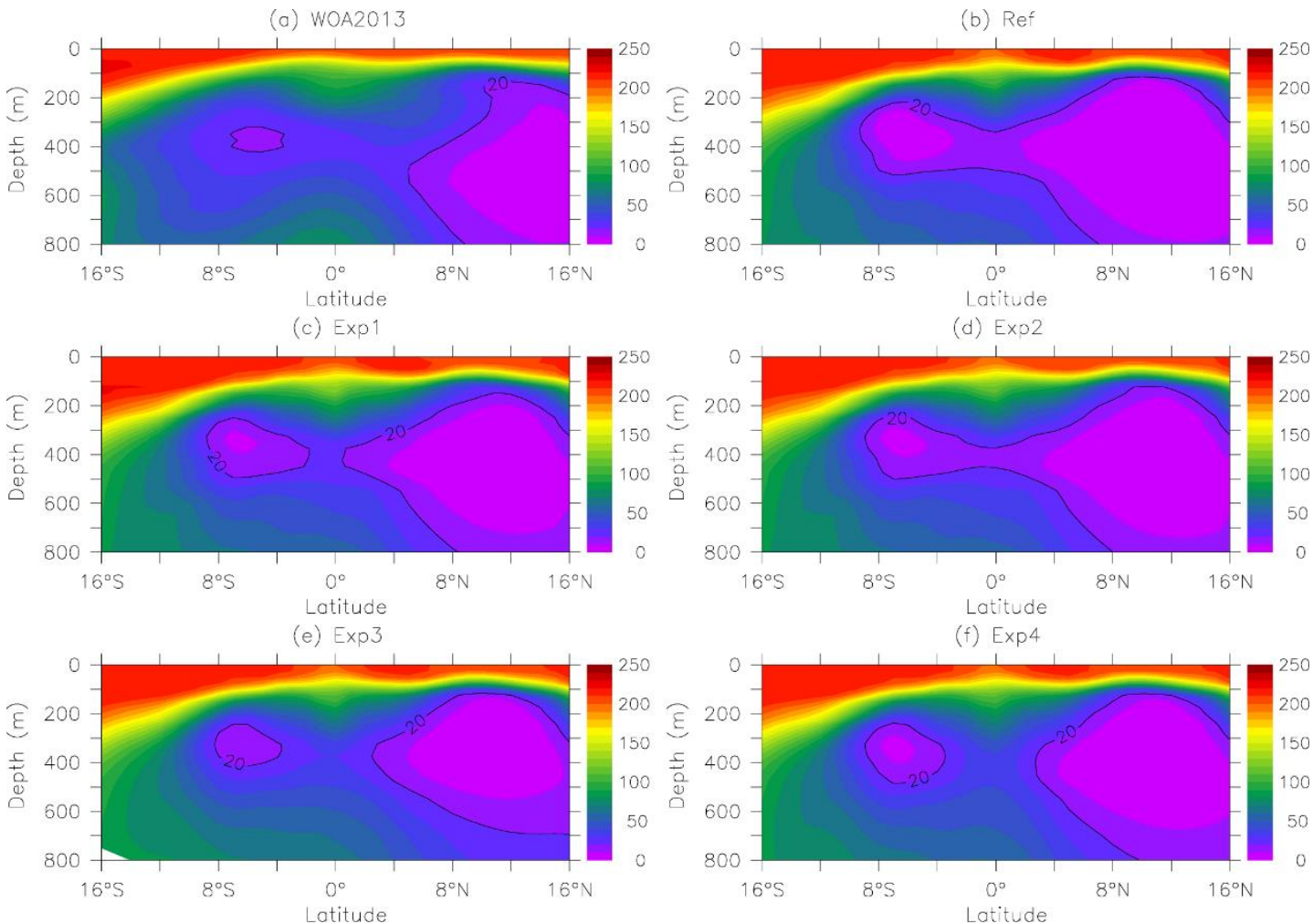

(d) Exp2

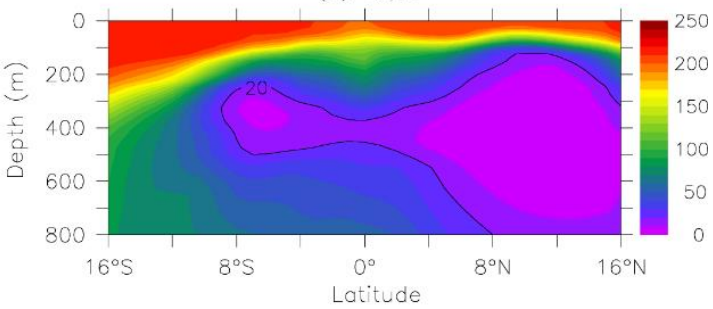

(f) Exp4

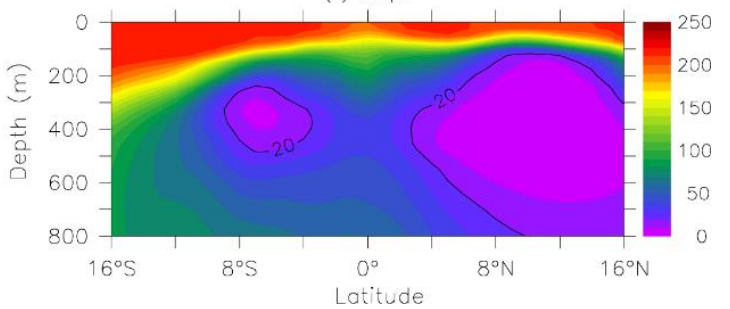

Figure 4. Observed and simulated mean DO concentrations $\left(\mathrm{mmol} \mathrm{m}{ }^{-3}\right)$ from sensitivity experiments over $130^{\circ} \mathrm{W}-90^{\circ} \mathrm{W}$. (a) WOA2013 data, (b) reference run, (c) Exp1, (d) Exp2, (e) Exp3, and (f) Exp4 for the period of 1981-2000. Superimposed black lines denote the borders of suboxic water $\left(<20 \mathrm{mmol} \mathrm{m}^{-3}\right)$ in $(\mathbf{a}-\mathbf{f})$. 
https://doi.org/10.5194/gmd-2020-105

Preprint. Discussion started: 29 July 2020

(c) Author(s) 2020. CC BY 4.0 License.

(c) (1)
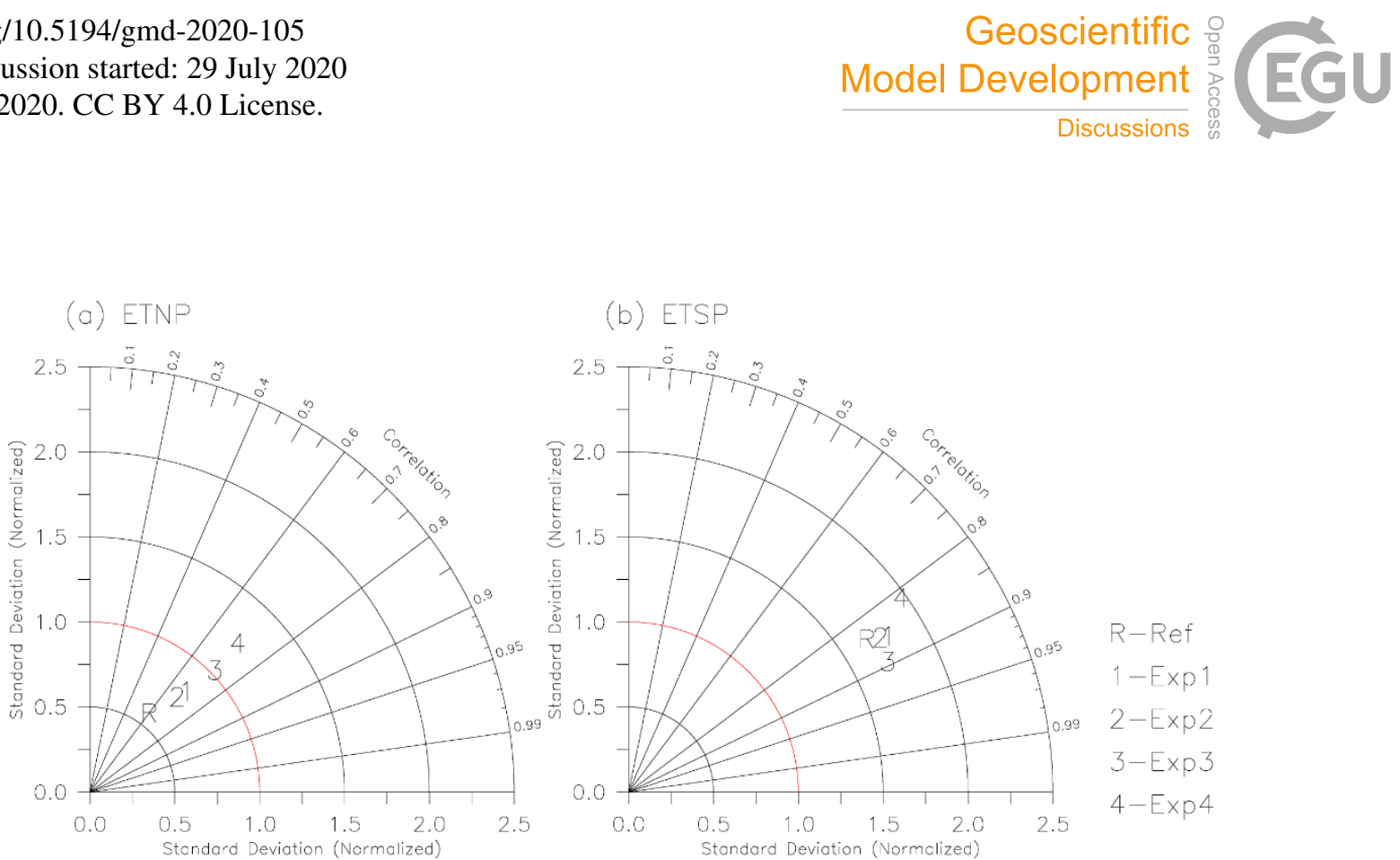

Figure 5. Taylor diagram for reference run and sensitive experiments comparing with WOA2013 data. Diagrams are shown for the two regions (a) ETNP and (b) ETSP. 
https://doi.org/10.5194/gmd-2020-105

Preprint. Discussion started: 29 July 2020

(c) Author(s) 2020. CC BY 4.0 License.

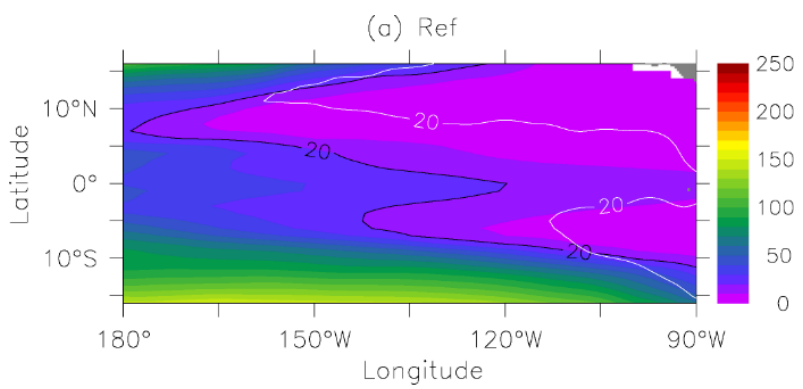

(b) $\operatorname{Exp} 3$

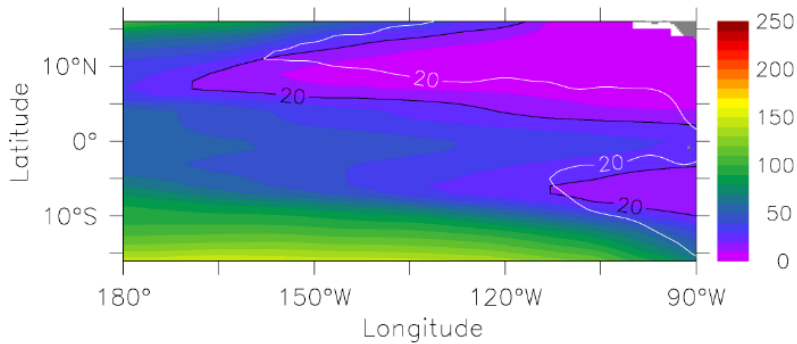

(c) Exp3 - Ref

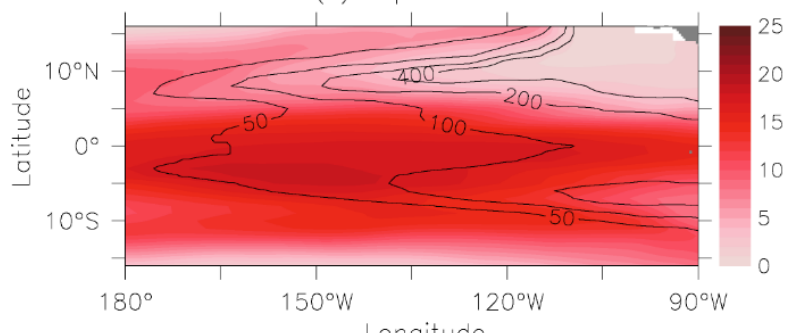

Figure 6. Modelled mean DO concentrations $\left(\mathrm{mmol} \mathrm{m}^{-3}\right.$ ) over 300-500 $\mathrm{m}$. (a) reference run, (b) Exp3, and (c) the difference between the means. Superimposed white and black lines in (a) and (b) denote the borders of suboxic water $\left(<20 \mathrm{mmol} \mathrm{m}^{-3}\right)$ from WOA2013 and model simulations, respectively. Superimposed solid black lines in (c) denote the percentage of DO change. 
https://doi.org/10.5194/gmd-2020-105

Preprint. Discussion started: 29 July 2020

(c) Author(s) 2020. CC BY 4.0 License.

(c) (i)

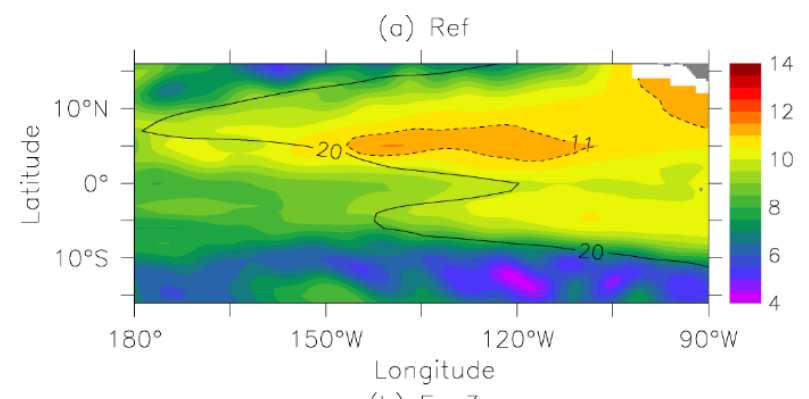

(b) $\operatorname{Exp} 3$

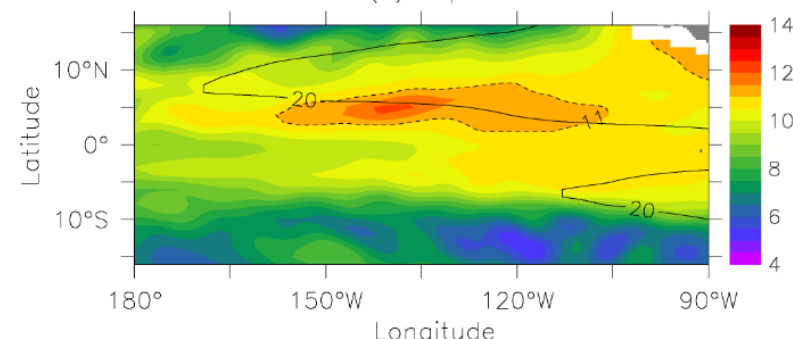

(c) $\operatorname{Exp} 3-$ Ref

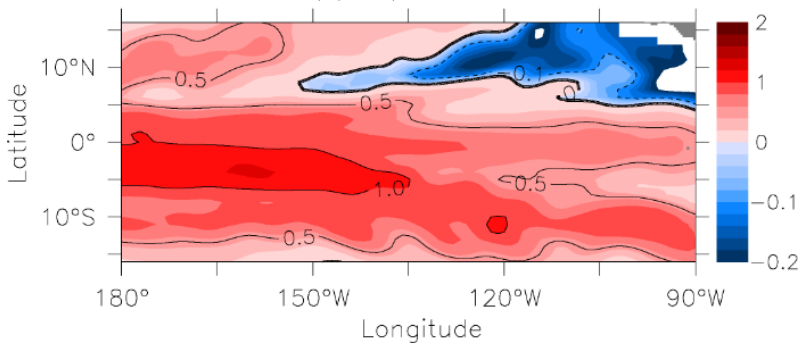

Figure 7. Physical supply (mmol m $\mathrm{m}^{-3} \mathrm{yr}^{-1}$ ) over $300-500 \mathrm{~m}$. (a) reference run, (b) Exp3, and c the difference between the means. Superimposed solid black lines in (a) and (b) denote the borders of suboxic water $\left(<20 \mathrm{mmol} \mathrm{m}^{-3}\right)$ from simulations. 
https://doi.org/10.5194/gmd-2020-105

Preprint. Discussion started: 29 July 2020

(c) Author(s) 2020. CC BY 4.0 License.

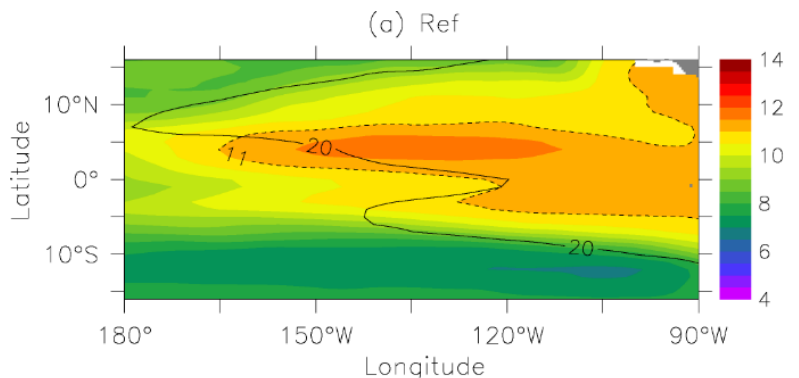

(b) $\operatorname{Exp} 3$

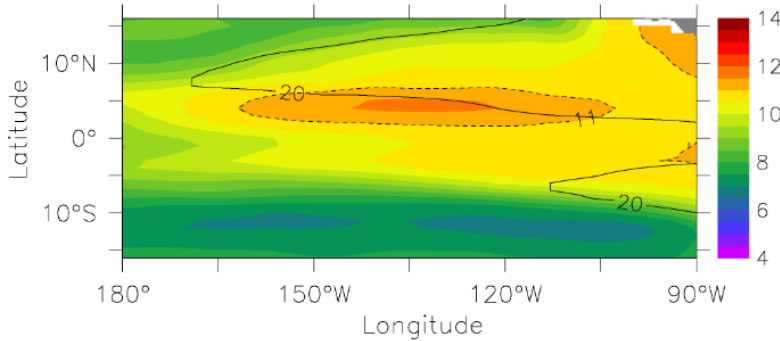

(c) Exp3 - Ref

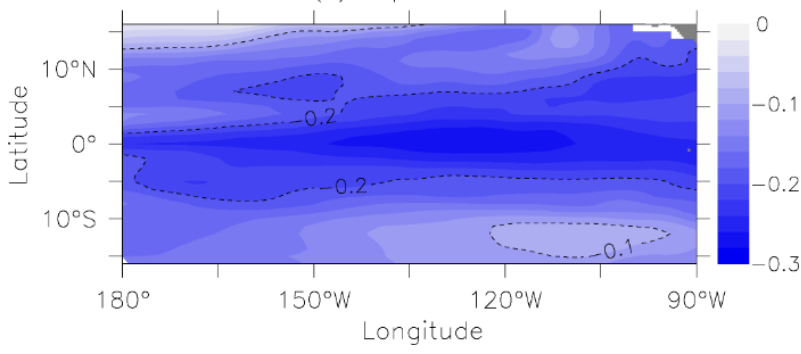

Figure 8. Biological consumption ( $\mathrm{mmol} \mathrm{m}^{-3} \mathrm{yr}^{-1}$ ) over 300-500 m. (a) reference run, (b) Exp3, and (c) the difference between the means. Superimposed solid black lines in (a) and (b) denote the borders of suboxic water $\left(<20 \mathrm{mmol} \mathrm{m}^{-3}\right)$. 
https://doi.org/10.5194/gmd-2020-105

Preprint. Discussion started: 29 July 2020

(c) Author(s) 2020. CC BY 4.0 License.

cc) (i)

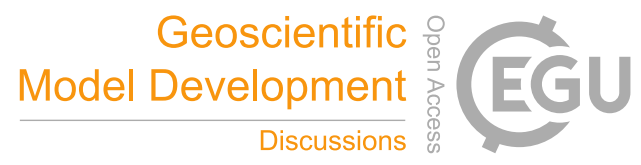

(a) Ref

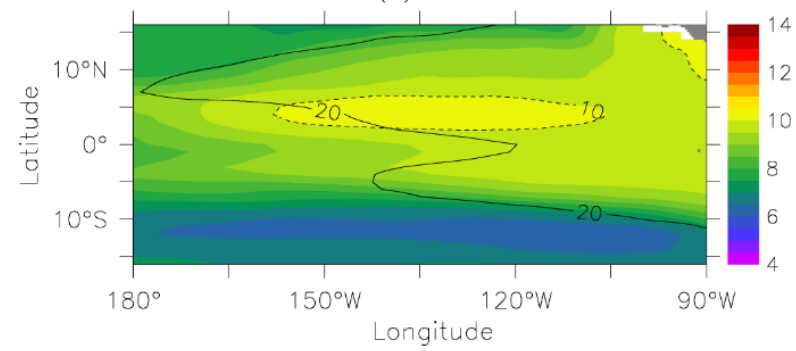

(c) Exp3

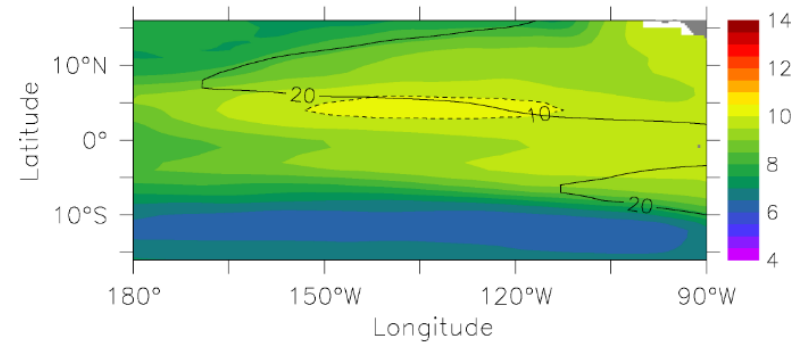

(e) Exp3 - Ref

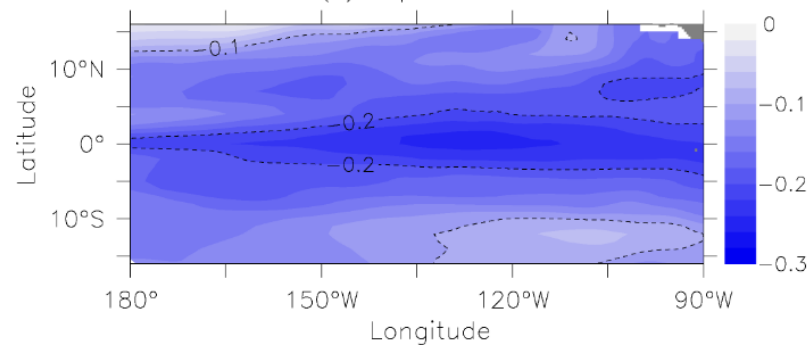

(b) Ref

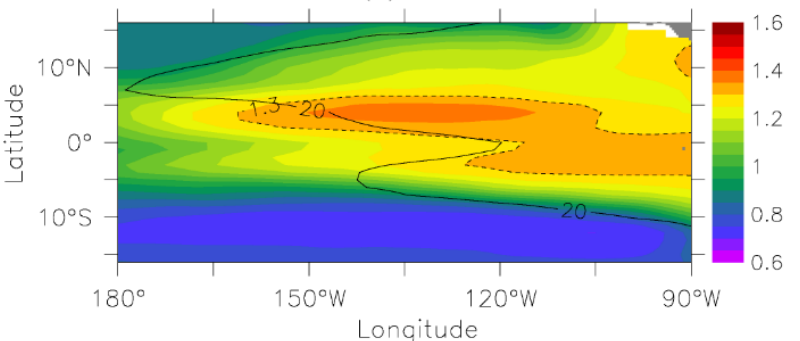

(d) $\operatorname{Exp} 3$

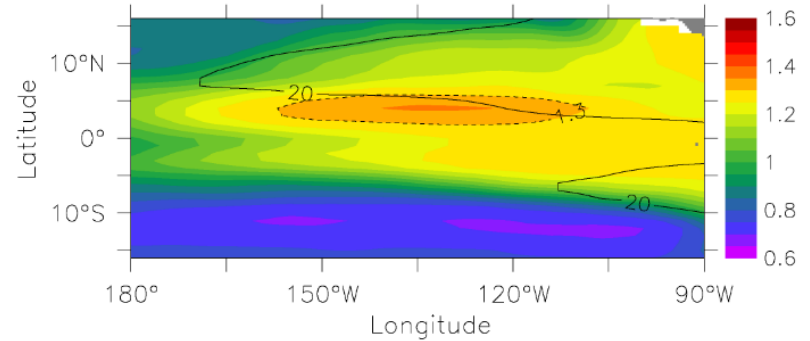

(f) $\operatorname{Exp} 3$ - Ref

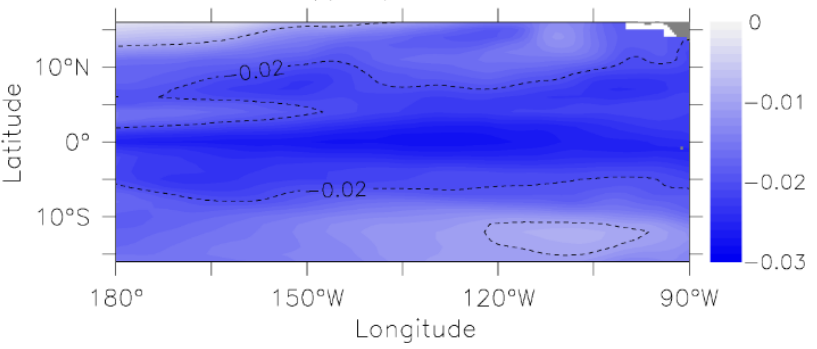

470 Figure 9. DOM remineralization (left panel, $\mathrm{mmol} \mathrm{m}^{-3} \mathrm{yr}^{-1}$ ) and POM decomposition (right panel, $\mathrm{mmol} \mathrm{m}^{-3} \mathrm{yr}^{-1}$ ). (a) and (b) reference run, and (c) and (d) Exp3, and (e) and (f) the difference between the means. Superimposed solid black lines in (a-d) denote the borders of suboxic water $\left(<20 \mathrm{mmol} \mathrm{m}^{-3}\right)$. 
https://doi.org/10.5194/gmd-2020-105

Preprint. Discussion started: 29 July 2020

(c) Author(s) 2020. CC BY 4.0 License.

(c) $\underset{\mathrm{BY}}{\mathrm{P}}$

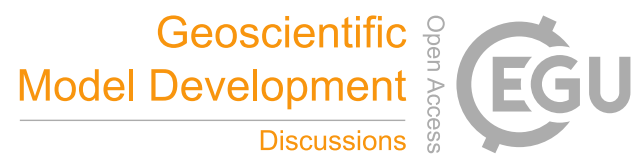

(a) Ref

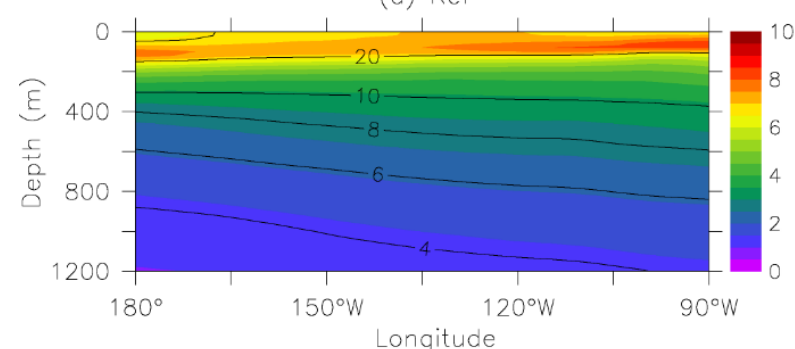

(c) Exp3

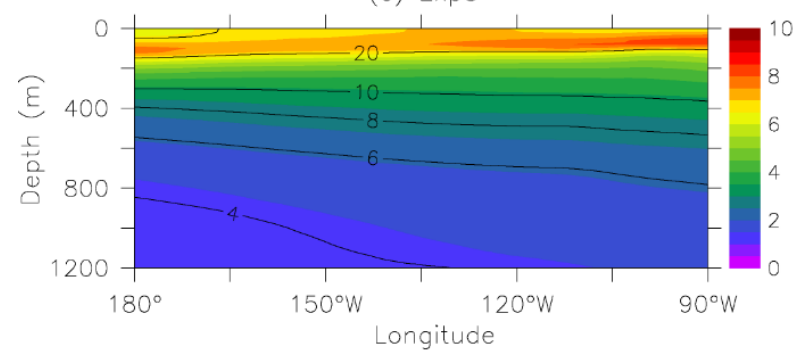

(e) Exp3 - Ref

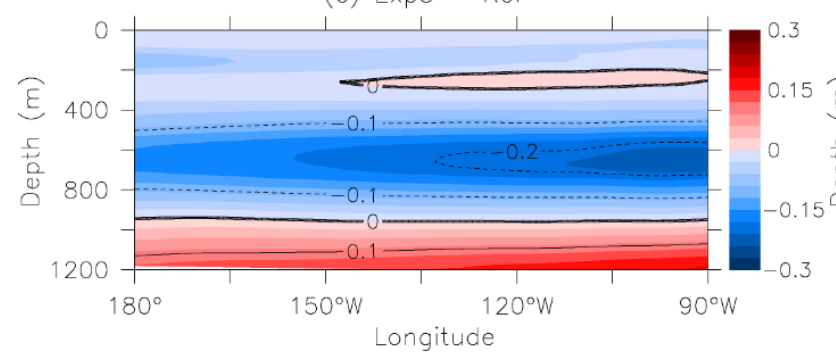

(b) Ref

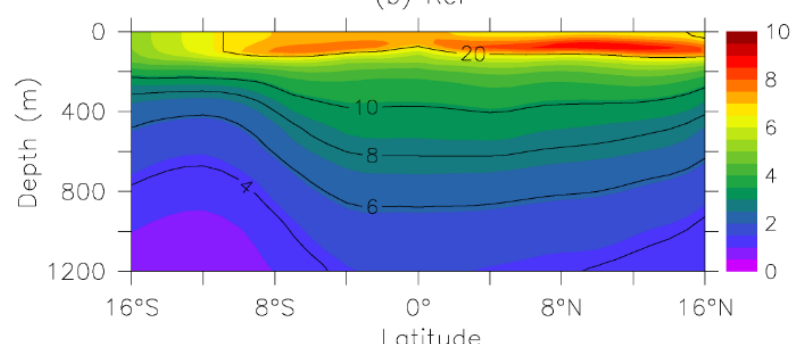

(d) $\operatorname{Exp} 3$

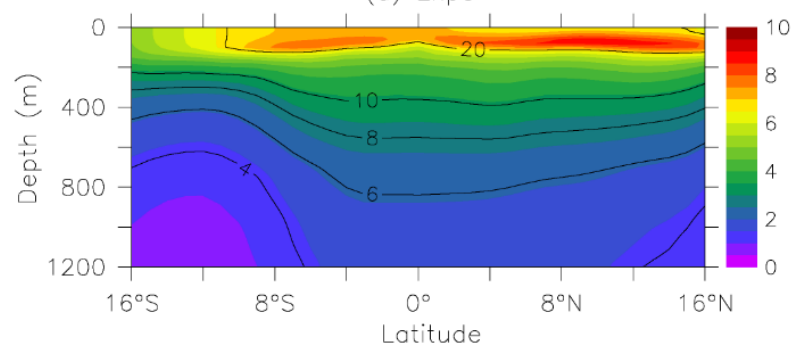

(f) $\operatorname{Exp} 3-R e f$

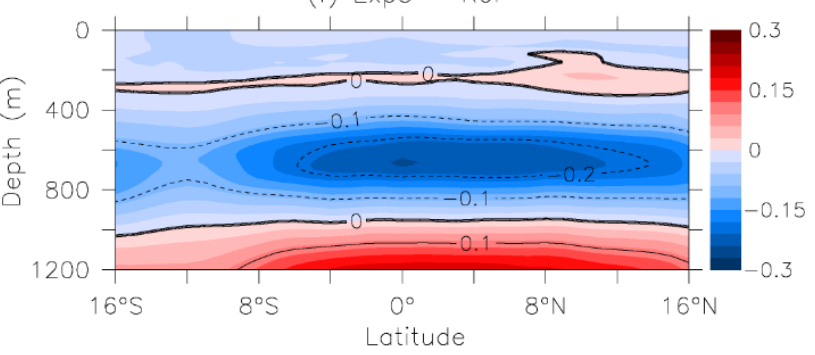

475 Figure 10. Mean DON concentrations $\left(\mathrm{mmol} \mathrm{N} \mathrm{m}{ }^{-3}\right)$ and DON remineralization $\left(\mathrm{mmol} \mathrm{m}^{-3} \mathrm{yr}^{-1}\right)$ over $10^{\circ} \mathrm{S}-15^{\circ} \mathrm{N}\left(\mathrm{left}\right.$ panel) and $130^{\circ} \mathrm{W}-$ $90^{\circ} \mathrm{W}$ (right panel). (a) reference run, (b) Exp3, and (c) the difference between the means. Superimposed black lines in (a-d) denote consumption rates $\left(\mathrm{mmol} \mathrm{m}^{-3} \mathrm{yr}^{-1}\right)$ by remineralization of DON. 
https://doi.org/10.5194/gmd-2020-105

Preprint. Discussion started: 29 July 2020

(c) Author(s) 2020. CC BY 4.0 License.

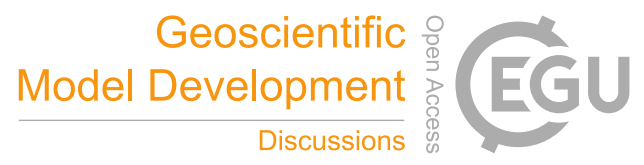

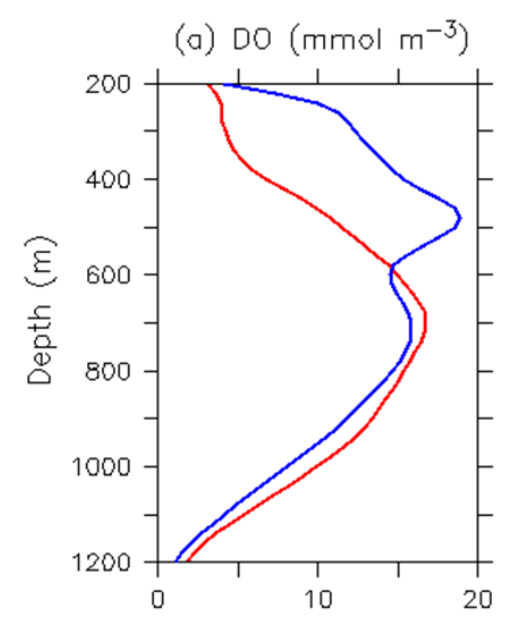
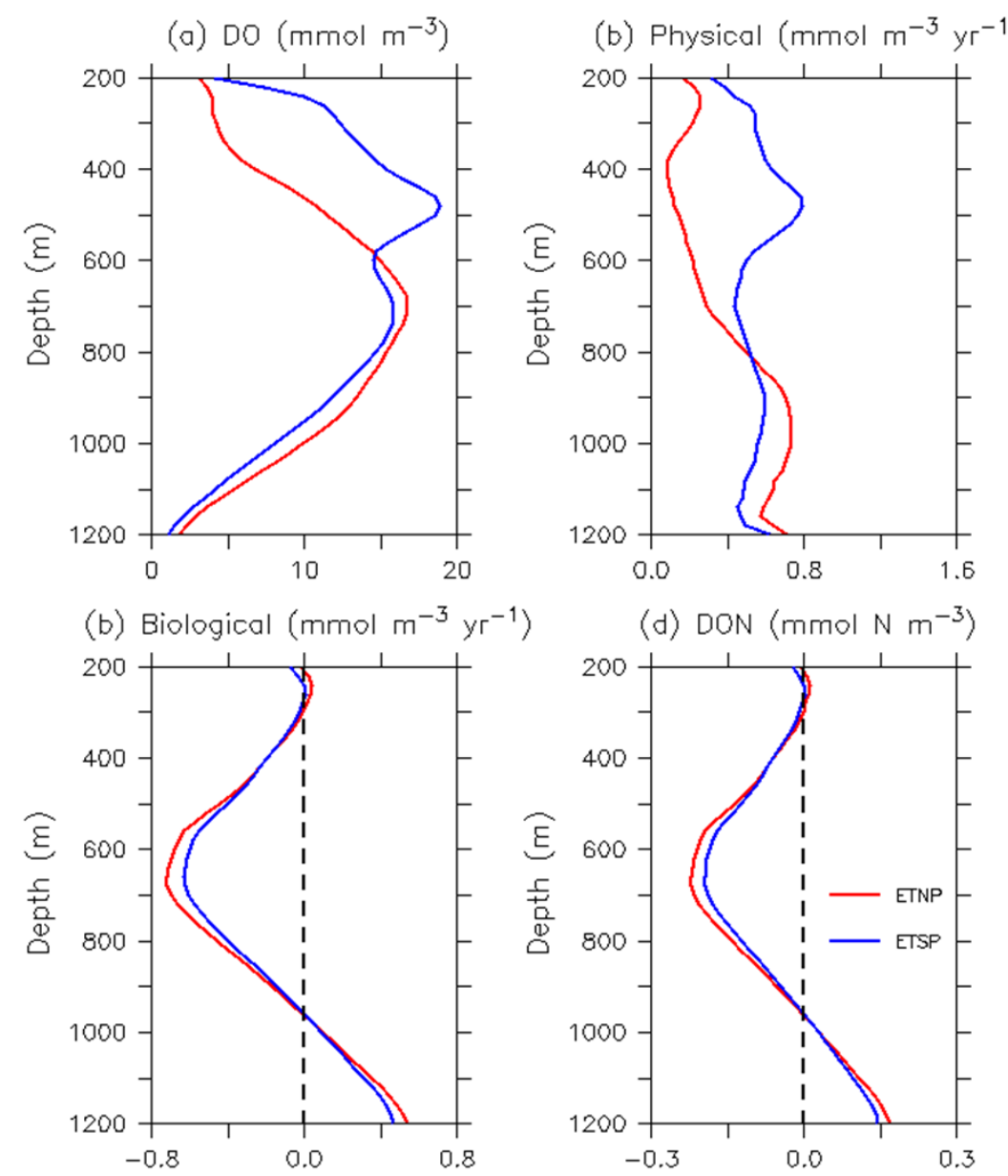

(d) DON ( $\mathrm{mmol} \mathrm{N} \mathrm{m} \mathrm{N}^{-3}$ )

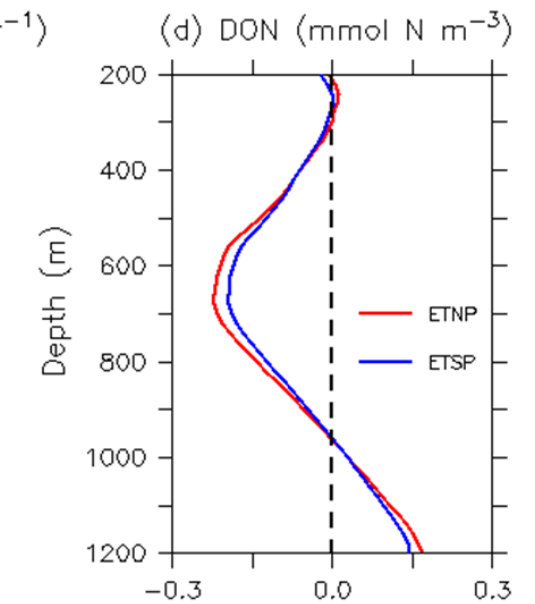

480 Figure 11. Comparisons between Exp3 and reference run (Exp3 minus reference run). (a) DO, (b) physical supply, (c) biological consumption, and (d) DON. Sections: ETNP (red lines) $\left(150^{\circ} \mathrm{W}-90^{\circ} \mathrm{W}, 0^{\circ} \mathrm{N}-15^{\circ} \mathrm{N}\right)$ and ETSP (blue lines) $\left(150^{\circ} \mathrm{W}-90^{\circ} \mathrm{W}, 10^{\circ} \mathrm{S}-0^{\circ} \mathrm{S}\right)$ 
https://doi.org/10.5194/gmd-2020-105

Preprint. Discussion started: 29 July 2020

(c) Author(s) 2020. CC BY 4.0 License.

\section{Tables}

Table 1. Model experiments with different parameters in biological and physical processes.

\begin{tabular}{llllllll}
\hline Parameter & Symbol & Unit & Ref & Exp1 & Exp2 & Exp3 & Exp4 \\
\hline Remineralization & $\mathrm{C}_{\mathrm{DON}}$ & $\mathrm{d}^{-1}$ & 0.001 & 0.0005 & 0.001 & 0.001 & 0.001 \\
O:C ratio & $\mathrm{R}_{\mathrm{OC}}$ & - & 1.3 & 1.3 & 1.0 & 1.3 & 1.3 \\
Partial mixing & $\mathrm{P}_{\mathrm{m}}\left(R_{i}>0.7\right)$ & $\mathrm{m}^{-2} \mathrm{~s}^{-1}$ & 0 & 0 & 0 & $10^{-4}$ & $\frac{3.5 \times 10^{-3}}{(0.7+R i)}+3 \times 10^{-5}$
\end{tabular}

$485 \mathrm{Ri}$ is Richardson number in the water column.

Table 2. Comparisons of DO over 300-500 m between WOA2013 data and model experiments for the period of 1981-2000 in the Eastern Tropical North Pacific (ETNP) and Eastern Tropical South Pacific (ETSP).

\begin{tabular}{llllll}
\hline & Ref & Exp1 & Exp2 & Exp3 & Exp4 \\
\hline ETNP $\left(150^{\circ} \mathrm{W}-90^{\circ} \mathrm{W}, 0^{\circ} \mathrm{N}-15^{\circ} \mathrm{N}\right)$ & -16.13 & -11.51 & -12.71 & -8.59 & -9.55 \\
Bias $\left(\mathrm{mmol} \mathrm{m}^{-3}\right)$ & 18.43 & 14.39 & 15.34 & 12.36 & 13.73 \\
RMSE $\left(\mathrm{mmol} \mathrm{m}^{-3}\right)$ & $0.599^{*}$ & $0.691^{* *}$ & $0.675^{* *}$ & $0.715^{* *}$ & $0.705^{* *}$ \\
Correlation coefficient & 0.581 & 0.820 & 0.761 & 1.027 & 1.234 \\
NSD & & & & &
\end{tabular}

$\operatorname{ETSP}\left(150^{\circ} \mathrm{W}-90^{\circ} \mathrm{W}, 10^{\circ} \mathrm{S}-0^{\circ} \mathrm{S}\right)$

$\begin{array}{llllll}\text { Bias }\left(\mathrm{mmol} \mathrm{m}^{-3}\right) & -14.70 & -7.09 & -8.96 & 1.05 & -2.71 \\ \text { RMSE }\left(\mathrm{mmol} \mathrm{m}^{-3}\right) & 15.51 & 9.87 & 11.04 & 8.43 & 9.69 \\ \text { Correlation coefficient } & 0.842 * * & 0.857 * * * & 0.852 * * * & 0.893 * * * & 0.814 * * \\ \text { NSD } & 1.666 & 1.784 & 1.740 & 1.709 & 1.971\end{array}$

Significances of correlation coefficient at 0.05, 0.01, and 0.001 levels are marked with one, two and three asterisks, respectively. 